\title{
Corporate Governance and Firm Value: The Impact of Chinese Companies' Corporate Social Responsibility
}

\author{
Dong Soon Kim,* Eunjung Yeo** and Ying-Ai Zhang***
}

\begin{abstract}
We investigate whether the corporate social responsibility (CSR) of Chinese companies has a certain impact on firm value, and further, depending on the level of corporate governance, how the impact of CSR on firm value changes. First, CSR activities generate a positive effect on firm value suggesting that companies may have an incentive to be willing and to continue to perform their CSR activities. Second, if the ratio of the largest shareholder's stake is low (high) or the gap between the largest and the second-largest shareholder's stakes is small (large), CSR activities lead to a significant positive (negative) impact on firm value. Third, we find a positive impact for firms with high management or auditor ownership and for firms whose CEO and chairman of the board are not the same person. Interestingly, due to the fact that significant numbers of outside directors of Chinese companies are appointed by the largest shareholders in China, CSR activity may be used to better align the company with the private interests of the largest shareholders than with the interests of other shareholders, thus lowering firm value. Lastly, if the company's largest shareholder is the country government, CSR has a positive impact on firm value. In this case, the largest shareholder - the country government-carries out CSR activities for social benefit because such a benefit is naturally aligned with the country's interests in the company. This paper also sheds light on Chinese companies' corporate governance structure that enhances socially responsible activities and firm value. Our results suggest that good governance provides incentives to voluntarily and continuously perform socially responsible activities.
\end{abstract}

Keywords: Corporate social responsibility, corporate governance, firm value, Chinese companies JEL Classifications: G32, G34, G38

\footnotetext{
* Professor, CAU Business School, Chung-Ang University, Seoul, Korea.

** Corresponding Author: Associate professor, CAU Business School, Chung-Ang University, Seoul, Korea.

*** Assistant Manager, Global Solution Team, Heungkuk Asset Management, Seoul, Korea.

Manuscript received June 13, 2016; out for review June 23, 2017; review completed August 7, 2017; accepted August 8, 2017.
}

The Korean Journal of Policy Studies, Vol. 32, No. 2 (2017), pp. 23-61.

(C) 2017 by the GSPA, Seoul National University 


\section{INTRODUCTION}

During the past decades, corporate social responsibility (hereinafter referred to as CSR) activities have emerged as an integral part of businesses, investors, governments, and other areas of society. Companies become major players in an economy, but also cause many business-related and social problems. Moreover, given the globalization of the world economy, CSR activities in foreign countries have become important. ${ }^{1}$ In fact, many companies dedicate a section of their annual reports and corporate websites to CSR activities, emphasizing the importance they attach to such activities. Chinese companies are no exception. ${ }^{2}$

However, in China, different from other developed or developing countries, the pace of the development of laws, regulations, and institutional systems has failed to keep up with the speed of economic growth. The credibility and image of the corporate sector have declined sharply because of the illegal and unfair practices of some companies. Recently, situations such as food made from waste materials, the illegal disposal of toxic substances, a harsh labor environment, and a heavy burden on employees have created a social sentiment that requires Chinese companies to dedicate more resources to CSR activities.

Since first introduced in the 1930s, CSR has been a main research topic in business practice and corporate governance. Friedman (1970) defines CSR as managing a company to enable it to create as much wealth as possible while obeying laws and ethical practices, which is a very narrow definition of CSR. In response, McWilliams and Siegel (2000) propose a more comprehensive definition of CSR activities as the act of creating a social good that goes beyond corporate interests and the requirements of the law. According to CSR theory, companies not only pay for benefits to shareholders but also must bear a certain amount of social responsibility by considering the interests of other stakeholders in society.

Despite significant research on CSR, previous studies provide mixed results on the effect of such activities on firm value (see Griffin and Mahon (1997), Orlitzky (2001), Orlitzky et al. (2003), Margolis and Walsh (2003), and Margolis et al. (2007) for reviews of the literature). Although there appears to be more support for the view that

1. For example, in 2012, Foxconn — known for assembling most of Apple's products-was linked to multiple employee suicides and poor working conditions, which in turn damaged Apple's company image.

2. For example, an article in World Economic Forum(2015) notes the importance of CSR for Chinese companies through change in strategic thinking by mentioning "... Today, leading Chinese companies seek to become some of the world's most reputable and pre-eminent brands and view CSR as a critical part of their transformation...." 
CSR activities are positively related to profitability and firm value, a large number of studies find the opposite relation. As a result, the normative implications of the research on CSR remain uncertain.

In this paper, we propose an indirect relation between CSR and firm value by considering the corporate governance structure. Similar to Servaes and Tamayo (2014), we also emphasize the channels through which CSR affects firm value. However, unlike them, we use the insight that the impact of CSR on firm value depends on the ability of CSR to influence shareholders and not stakeholders of the firm. We first focus on the effect of CSR activities on firm values using an empirical analysis of Chinese listed companies. We then determine whether these activities additionally incur costs to companies or are a good business practice that enhances firm value.

Although most previous studies focus only on the relation between CSR activities and firm value, we further analyze whether this relationship depends on the corporate governance structure, which is a key contribution of the paper. Corporate governance is a mechanism for protecting external investors, improving the value of the company, and maximizing shareholder value (Beltratti 2005). The consensus is that corporate governance is positively related to firm value (Lemmon and Lins 2003; Allen et al. 2005). If CSR activities increase a company's value, companies with good corporate governance are more likely to be more actively engaged in CSR activities. ${ }^{3}$ Kook and Kang (2011) analyze the relationship between corporate governance and CSR using Korean company data and show that companies with better corporate governance more actively engage in CSR activities.

In our analysis, we employ data on Chinese publicly listed companies from 20082010, which cover the CSR activities of a large subset of Chinese companies, and combine them with their financial statement data. Our main performance metric is Tobin's Q, which is the market value of the firm divided by the replacement value of its assets. We start by assessing whether firms with high corporate governance measures can enhance firm value by increasing CSR activities, and find this to be the case in models that employ firm fixed effects. CSR activities have a negligible or negative impact on firm value for firms with low corporate governance measures, suggesting that the costs of CSR activities may outweigh the benefits for these firms. However,

3. Due to the weak corporate governance structure, if managers can enjoy private benefits, they can pursue CSR activities for the purpose of promoting their own private benefits in contrast to corporate value. At this time, those CSR activities carried out to pursue the private interests of managers can be profitable for managers only. For shareholders, it will be the cost of the amount spent for CSR activities, so firm value will be undermined by it. The better the corporate governance structure, the more likely the CSR activities are to be effectively controlled. 
we find a positive impact for firms with high management or auditor ownership and for firms whose CEO and chairman of the board are not the same person. Moreover, because significant numbers of outside directors of Chinese companies are appointed by the largest shareholders in China, CSR activities may be used to better align the company with the private interests of the largest shareholders than with the interests of other shareholders, thus lowering firm value. Lastly, if the company's largest shareholder is the country, CSR has a positive impact on firm value. In this case, the largest shareholder - the country - carries out CSR activities for social benefit because such a benefit is naturally aligned with the country's interests in the company.

This article contributes to the debate on the role of CSR in corporate strategy. This research is important because it presents the first empirical evidence from an examination of whether corporate governance measures are associated with improved financial value through CSR activities for Chinese companies. This study can potentially alert policymakers in developing countries to the increasing overlap between corporate governance and CSR agendas, the need to reform the regulatory and judicial systems from the context of corporate governance structure, and to increase institutional pressure to enhance CSR adoption.

The remainder of this paper is organized as follows. Section 2 presents the background, related studies, and research hypotheses. Section 3 describes the sample selection, the variables, and the regression model. Section 4 presents the empirical results. Finally, Section 5 concludes the paper and provides implications.

\section{LITERATURE REVIEW AND HYPOTHESES}

\section{CSR and Firm Value}

Previous empirical research on the relationship between CSR and corporate value shows mixed results. Many empirical studies find that companies' CSR activities have positive effects on their financial performance. Prior studies such as Bowman and Haire (1975), Heinze (1976), and Sturdivant and Ginter (1977) present the results of increased financial performance from a company's CSR activities. Cochran and Wood (1984) investigate the financial performance of 36 companies from 1979 to 1975 and of 39 companies from 1970 to 1974. They find a positive correlation between CSR activities and financial performance, proxied by financial variables such as return on assets (ROA), return on sales, and market valuations. Preston and O'Bannon (1997) analyze data on 67 large companies in the United States from 1982 to 1992 and find a strong positive relation between CSR activities and financial performance, including 
ROA and return on equity (ROE). In the 1990s, Waddock and Graves (1997) investigate data on S\&P 500 companies and find that both a company's prior and future financial performance, as indicated by debt-to-equity ratio, ROA, and equity returns, are positively associated with corporate social performance activities as measured using the KLD index. Using Korean company data, Kim (2009) demonstrates that the value of companies performing CSR activities is higher. He argues that, although CSR activities generate costs in the short term, they enhance the reputation of the company, increase sales, and lower costs in the long term.

In contrast, claims have been made that CSR activities negatively influence a company's financial performance. Bragdon and Marlin (1972) argue that companies' CSR activities have an adverse impact on competition because of the increase in companies' costs compared with that of competitors. Vance (1975) measures the financial performance of a company using the percentage change in its stock price and measures CSR using Milton Moskowitz's social responsibility rating. He finds that the stock prices of corporates with a higher CSR grade are actually lower. The additional costs incurred to fulfill social responsibilities lowers companies' profits.

Some studies take a neutral stance. Unlike the aforementioned studies, Ullmann (1985) argues that finding reasons regarding the relationship a company's social responsibility and financial performance is difficult. Zheng Li (2006) studies the relationship between CSR and corporate value by analyzing 521 Chinese companies listed on the Shanghai Stock Exchange in 2003. Using stakeholder theory and social capital theory, he concludes that, although the value of firms engaging in more social responsibility activities are lower in the short run, CSR activities do not reduce firm value in the long run.

In all, claims of a negative relationship between CSR and corporate value emphasize the additional costs incurred to perform CSR activities, which can be a competitive disadvantage. In contrast, claims of a positive relationship argue that the costs of CSR activities are relatively small compared with their benefits. More CSR activities enhance a company's image and improve relationships between employees and other stakeholders - ultimately resulting in higher firm value.

We expect that investments in CSR activities in areas such as labor relations, environmental issues, and community development will assist in improving the corporate image, maintaining a smooth relationship between the community and employees, and attracting better workers in the long run. In contrast, if a company avoids engaging in CSR activities to reduce its short-term costs, it may fail to meet stakeholder expectations. Such a company may face more problems and lawsuits in the long run.

For example, the fine for excessive pollution or the cost to recall products with defects can be larger without CSR activities. The damage to a company's image and 
reputation is also more significant (Tsoutsoura 2004). Most of all, companies voluntarily continue to perform CSR activities only if they have a positive impact on longterm firm values (Guk and Gang 2011). In this paper, we develop the following hypothesis regarding the impact of a company's social responsibility activities on firm value.

H1: Corporate social responsibility activities increase the value of the firm.

\section{Effects of corporate governance on the impact of CSR activities on firm values}

If a company's CSR activities can increase its firm value, CSR activities can be regarded as a business strategy and managers may select the level and extent of these activities. In this case, agency costs associated with CSR activities may occur. Executives may abuse their rights by selecting a CSR policy that does not correspond to shareholder interests but, instead, enhances private interests. In other words, if managers can enjoy private benefits, such as enhancing their own reputations by performing CSR activities, they have an incentive to engage in such activities regardless of the effect on firm value (Jensen and Meckling 1976). Therefore, we expect that the impact of corporate CSR activities varies depending on corporate governance, including ownership and board structures.

H2: The effects of corporate social responsibility activities on firm values differ depending on the degree of corporate governance.

Studies on the ownership structure of Chinese companies focus on the concentration of corporate ownership, the characteristics of the ownership, and insider shareholdings. Two arguments are related to concentration of ownership. One argument states that companies with more concentrated ownership are better at executive monitoring through the majority shareholder. In contrast, the other argument states that majority shareholders may expropriate the interests of the minor shareholders for their own interests.

Monitoring theory argues that majority shareholders who expect high returns have a strong incentive to monitor managers and prevent behavior that may harm shareholder interests. The empirical result of Morck et al. (1988) shows that, as the largest shareholder holdings ratio increases, agency costs are likely to decrease because the majority shareholder reduces the conflicts of interest between managers and shareholders by overseeing managers' opportunistic behavior.

In contrast, other empirical research provides different results and finds negative 
effects of ownership concentration on firm value. Leech and Leahy (1991) obtain the result that ownership concentration has a significant negative effect on firm value. Shleifer and Vishny (1986) argue that, in some countries, the agency problem occurs more in the conflict between the majority shareholder and minority shareholders than between managers and shareholders. In this circumstance, the interests of the majority shareholders and minority shareholders are not aligned. In this case, major shareholders can abuse their rights and ineffectively allocate company resources, and the cost of owning shares can be very large to minority shareholders. Therefore, if the ratio of the largest shareholder's holdings is high, or if the difference between the ratio of the largest shareholder's holdings and that of the second largest shareholder's holdings is sufficiently large, the largest shareholder may be able to proceed with CSR activities for private benefit, which may have a negative effect on firm value.

H2-1: A lower ratio of the largest shareholder's holdings results in a higher firm value.

H2-2: Corporate social responsibility activities lead to higher firm values if the difference in the holdings ratio between the largest and the second largest shareholders is small, and leads to lower firm values if this difference is large.

Shareholdings by management can provide an incentive for executives to maximize the value of the shares and increase corporate control by shareholders by aligning executives' and shareholders' interests. Many previous studies claim a positive relationship between management ownership and corporate value, and describe this relationship as a mechanism to align the interests of executives and shareholders (Demsetz 1983; Hill and Snell 1989; Morck et al. 1988; Cho 1998).

Shares owned by executives can cause managers' and shareholders' interests to converge. Berle and Gardiner (1932) state that a potential conflict of interest arises from the separation of ownership and corporate control. Later, Jensen and Meckling (1976) propose the incentive alignment hypothesis: as managers' shares increase, the interests of managers and shareholders converge and, therefore, agency costs decrease. Sometimes, managers allocate company resources for their private interest, which creates conflicts with external shareholders. However, the manager-owner of a company has incentives to fulfill these shareholders' needs because both parties' incentives are more aligned. A recent empirical study of U.K. companies by Florackis (2008) concludes that a high management shareholding ratio reduces agency costs.

However, the management entrenchment hypothesis (Stulz, 1990) states that, as managers' shares increase, outside threats from the market decrease and the utility 
from seeking private benefit exceeds the utility from an increase in firm value. These effects lead to managerial entrenchment.

In this study, we choose the incentive alignment hypothesis and expect that a higher ratio of executive management shareholdings indicates better alignment of their interests with that of external stakeholders, thus mitigating the conflict of interest issue. That is, a higher ratio of management shareholdings indicates that CSR activities are geared more toward the interests of shareholders than the private interests of executives.

H2-3: CSR activities have a positive effect on firm value if the ratio of managers' shares is high, but a negative effect if the ratio is low.

Another way to reduce agency costs is to increase directors' or the audit committee's shareholdings, which is the same concept as executives' shareholdings, by aligning their interests with those of shareholders (Jensen 1993). If executives receive just a fixed salary, they may act to enhance their personal short-term interests rather than those of shareholders. In contrast, if directors or audit committee members own shares of the company, they will more actively monitor managers' behavior and propose management strategies that benefit both shareholders and themselves. According to claims by Mace (1986), monitoring efficiency can increase when directors or audit committee members possess adequate shares of stock. Kren and Kerr (1997) demonstrate that the ratio of director shareholdings has a positive effect on firm value.

We expect that directors' or audit committee members' shareholdings result in stronger incentives and motivation to oversee CEO behavior. Thus, CSR strategy is carried out to increase firm value. We also expect that this notion is valid for shares held by audit committee members.

H2-4: If the ratio of directors' shares is high (low), CSR has a positive (negative) effect on firm value.

H2-5: If the ratio of the audit committee's share is high (low), CSR has a positive (negative) effect on firm value.

The claims as to whether the CEO and chairman of the board of directors should be different people are conflicting — often referred to as the CEO-duality problem. Agency theory predicts that when corporate ownership and management rights are separated, agency problems occur because of (i) conflicts of interest between managers, including the CEO, and shareholders and (ii) incomplete information (or information asymme- 
try). Agency theory assumes that agents are selfish and monitoring is necessary to prevent executives from making self-serving decisions. The board of directors needs to play this supervisory role. However, if the CEO and the chairman of the board are the same person, agency theory predicts that executive directors are highly likely to pursue private benefits rather than maximize shareholders' interests.

In contrast, stewardship theory (Donaldson and Davis 1991) assumes that individuals are organization oriented and pro-organizational and argues that executives rather choose to serve the interests of the organization and maximize shareholder value than pursue their private interests. Similarly, Boyd (1995) claims that executives are likely to seek self-satisfaction and fulfillment more than private benefits. In all, if stewardship theory is true, it predicts that CEO-duality provides more freedom to executives and leads to rapid decision making, which leads to higher firm value.

We choose the more conventional view-agency theory-that indicates that individuals are self-centered. We assume that it is possible that CEO-directors perform CSR activities for private benefit.

H2-6: If the CEO and chairman of the board are not the same person, CSR has a positive effect on firm value.

Fama and Jensen (1983) emphasize the importance of the board's role of supervision and control over management. To reduce management's pursuit of private benefits, setting up an institution such as the board of directors and the audit committee is necessary to monitor executives' behavior. The main role of the board of directors and the audit committee is to mitigate conflicts of interest between shareholders and management, minimize agency costs, and protect the interests of shareholders. Beasley et al. (2000) demonstrate that financial statement fraud is less prevalent among firms with a strong audit committee.

Further, according to resource dependence theory (Pfeffer amd Salancik 2003), organizations such as the board of directors or the audit committee can assist in accessing the company's information and providing important feedback for setting the company's direction. Zahra and Pearce (1989) also claim that directors or an audit committee can provide connections to competitors and other stakeholders and help a company acquire important information, skills, reputation, and other resources.

Thus, if the board of directors or audit committee is large, its supervisory role will be enhanced and CSR will be carried out to improve firm value rather than to benefit the company's major shareholders or CEO. The opinions and views of the directors or audit committee members are also expected to help the effective CSR activities. 
H2-7: If the board of directors is large (small), CSR activities have positive (negative) effects on firm value.

H2-8: If the audit committee is large (small), CSR activities have positive (negative) effects on firm value.

Independence of outside directors is indispensable for effective governance and discipline. We can easily find evidence to support the following relationship: a higher proportion of outside directors at a firm results in discipline being exerted more effectively over management and, thereby, in better firm performance. A review article by Hermalin and Weisbach (2003) also supports the causality previously mentioned. Their main conclusions are that a higher proportion of outside directors leads to a higher probability that the CEO will be replaced when corporate performance declines and lower CEO compensation, which are consistent with the hypotheses considered in this paper. ${ }^{4}$ However, for Chinese companies, the largest shareholders or chief executive officers often appoint directors of other large companies as outside directors of their own companies. Such an appointment process might be one reason for the damage to the independency of outside directors in China. Because major shareholders or managers can nominate outside directors, their relationship is not for supervision and monitoring but for cooperation and accordance (Ma Qingyun, 2013).

Westphal (1998) also show that executives use their power to influence the process of selecting directors and their decision making. They are involved in appointing directors who primarily support their managerial decisions.

We expect that the largest shareholder and the executives are more willing to perform CSR activities for their own benefit. In this case, a company with a higher proportion of outside directors who primarily support the executives (the so-called gray directors) is expected to have a lower firm value from CSR activities.

H2-9: CSR has a positive (negative) effect on firm value if the proportion of outside directors at a firm is low (high).

A significant number of Chinese companies are state owned. There are conflicting claims about the effects on firm value when the largest shareholder is the government in China. Tian (2005) demonstrates that the financial performance of state-owned

4. For details, refer to their paper. However, note that no significant relationship exists between the proportion of outside directors and the corporate performance measured using accounting income or stock returns. 
companies is generally lower than that of private companies. The explanation is that, although governments provide a variety of preferential treatment for state-owned companies, they also take significant profits from these companies. Chen Xinyuan and Huang Jun (2007) argue that the government puts more emphasis on the realization of political objectives and social functions than on the company's interests and, thus, greater interference is observed in the management of state-owned companies. $\mathrm{Xu}$ Xiaodong and Chen Xiaoyue (2003) claim that private companies have higher firm values because they receive more external oversight and make more aggressive decisions than state-owned companies to survive market competition.

In contrast, some scholars argue that state ownership can increase firm value. Liu Yuanyuan et al. (2011) demonstrate that the ratio of a company's state ownership shows a significantly positive correlation with financial performance. Liao Guan Min and Chen Yan (2007) argue that when state-owned companies face financial distress, the government reduces the capital costs of these companies through support from the government's budget, which positively affects the company's financial performance. Sun et al. (2002) use Chinese company data from 1994 to 1997 and find that the ratio of state-owned shareholdings has a positive effect on firm value.

Because the ultimate purpose of the government is to maximize social welfare rather than company profits, CSR activities may be regarded as the realization of a national policy if the company's controlling shareholder is the government. We expect that if the company's largest shareholder is the government, CSR activities positively affect firm value because agency costs are not incurred as a result of their implementation.

H2-10: CSR activities show positive (negative) effects on firm values if the largest shareholder is (not) the government.

\section{Relationship between corporate governance and CSR activities}

Corporate governance is a mechanism for protecting external investors, improving the value of a company, and maximizing shareholder value (Beltratti, 2005). If CSR activities increase a company's value, companies with good corporate governance are more likely to be more engaged in CSR activities. Guk and Gang (2011) analyze the relationship between corporate governance and CSR with Korean company data and show that companies with better corporate governance are more active with CSR activities. Choi (2013) studies the correlation between corporate governance variables and capital costs and concludes that a higher ratio of the largest shareholdings results in lower CSR activities.

Wang and $\mathrm{Bu}$ (2012) study Chinese food manufacturers and find that the ratio of 
the largest shareholder of a company has a negative impact on CSR activities. They also found that the size of the board is positively correlated with CSR activities. Xie (2011) also finds a strong relationship between corporate governance structure and CSR activities, indicating that the ratio of the largest shareholder's holdings has a negative effect on CSR activities and state ownership has a positive effect.

Therefore, companies with better corporate governance, that is, companies with lower agency costs, are expected to engage in more CSR activities.

H3: Good governance structure and practices are positively associated with CSR activities.

\section{DATA AND EMPIRICAL ANALYSIS}

\section{Data}

This study uses data from 2008-2010. Data were collected on 277 Chinese companies listed on the Shanghai Stock Exchange and Shenzhen Stock Exchange (Shanghai Stock Exchange 90, Shenzhen Stock Exchange 63), and that met the following conditions:

(1) does not belong to the financial sector;

(2) has a fiscal year end of December 31; and,

(3) has CSR score data for three consecutive years, from 2008 to 2010.

The financial sector is excluded because it is regarded as highly regulated, indicating that heterogeneity exists when comparing its financial characteristics with those of the nonfinancial sector. The industry classification for the sample companies is represented in $<$ Table $1>$.

Table 1. Industry Classification of the Sample Companie

\begin{tabular}{l|c|c|c}
\hline & \multicolumn{2}{|c|}{ Exchange } & \\
\hline Industry classification & Shanghai & Shenzhen & Total \\
\hline Manufacturing & 90 & 63 & 153 \\
\hline Transportation & 21 & 2 & 23 \\
\hline Electricity, gas, utilities & 16 & 4 & 20 \\
\hline
\end{tabular}




\begin{tabular}{l|r|r|r}
\hline Telecommunication & 14 & 6 & 20 \\
\hline Mining & 9 & 3 & 12 \\
\hline Construction & 6 & 2 & 8 \\
\hline Wholesale, retail & 6 & 3 & 9 \\
\hline Real estate, rent & 4 & 9 & 13 \\
\hline Service & 4 & 2 & 6 \\
\hline General & 4 & 5 & 9 \\
\hline Agriculture, Forest, Fishery & 1 & 1 & 2 \\
\hline Entertainment, Culture & 1 & 1 & 277 \\
\hline Total & $\mathbf{1 7 6}$ & $\mathbf{1 0 1}$ & $\mathbf{2 7 7}$ \\
\hline
\end{tabular}

\section{Empirical Analysis}

\section{Variables}

The definition of the key variables for the empirical analysis and their measurement method are summarized in $<$ Table $2>$.

Table 2. Definition of the Key Variables

\begin{tabular}{|c|c|c|}
\hline Variables & Definition & Measurement \\
\hline \multicolumn{3}{|c|}{ Dependent variable } \\
\hline Value & Firm value & Tobin's Q \\
\hline \multicolumn{3}{|c|}{ Explanatory variables } \\
\hline CSR & A firm's CSR activities & RLCCW's CSR activity score \\
\hline CR1 & $\begin{array}{l}\text { The largest } \\
\text { shareholder's holding } \\
\text { ratio }\end{array}$ & $\begin{array}{l}\text { The largest shareholder's holdings/total } \\
\text { outstanding shares }\end{array}$ \\
\hline Z & $Z$ index & $\begin{array}{l}\text { The largest shareholder's holdings/second } \\
\text { largest shareholder's holding }\end{array}$ \\
\hline manageshr & Managers' share ratio & $\begin{array}{l}\text { Mangers' shareholdings/total outstanding } \\
\text { shares }\end{array}$ \\
\hline directshr & Directors' share ratio & $\begin{array}{l}\text { Directors' shareholdings/total outstanding } \\
\text { shares }\end{array}$ \\
\hline
\end{tabular}




\begin{tabular}{l|l|l}
\hline supervisorshr & Auditors' share ratio & $\begin{array}{l}\text { Auditors' shareholdings/total outstanding } \\
\text { shares }\end{array}$ \\
\hline$P$ & $\begin{array}{l}\text { CEO and chairperson } \\
\text { are or are not the same } \\
\text { individual }\end{array}$ & $\begin{array}{l}\text { If CEO and chairperson are the same, then 1; } \\
\text { otherwise 0 }\end{array}$ \\
\hline dsize & Size of board & Number of directors on the board \\
\hline ssize & $\begin{array}{l}\text { Size of supervisory } \\
\text { committee }\end{array}$ & Number of auditors \\
\hline Indep_ratio & $\begin{array}{l}\text { Ratio of independent } \\
\text { directors }\end{array}$ & Independent directors/total directors \\
\hline stateowner & State-owned & If state-owned then 1; otherwise 0 \\
\hline Control variables & Size of a firm & Natural logarithm of total assets \\
\hline SIZE & Earnings per share & Net income/total shares outstanding \\
\hline EPS & Debt to equity & Debt/total equity \\
\hline LEV & Growth rate of assets & Growth rate of assets \\
\hline GRW & &
\end{tabular}

Corporate governance structure and financial statement data for the sample were collected through the CSMAR database and from CCER data. Data related to CSR activities were used, and the CSR scores were published by the Rankins CSR Ratings (RKS) 2008-2010. Founded in 2007, RKS is known as a prestigious rating agency that assesses the social responsibility of enterprises in China and provides objective and scientific assessments of CSR information.

The RKS rating system used in this study is as follows. A score is composed of four columns, including Macrocosm (full configuration), Content (information), Technique (technology), and Industry (industry). Under the four columns are 15 sub-items. The company's experts evaluate the social responsibility report submitted by the companies on a scale of 100 points. The ratios of the four columns-Macrocosm, Content, Technique, and Industry - are 30\%, 45\%, 15\%, and 10\%, respectively. The evaluation system is shown in detail in $<$ Table $3>$. Industry trends of CSR scores and yearly CSR scores in the sample are summarized in $\langle$ Table $4>$.

Tobin's Q ratio is used as a proxy variable of firm value and is obtained by dividing the sum of the market capitalization and the book value of total debt by the book value of total assets. Other variables that affect firm value are presented, as well as the corporate governance variables already included in the study. As control variables in this study, the natural logarithm of market capitalization as a proxy for firm size, earnings per share, debt to equity ratios, and growth in total assets are adopted. 
Table 3. Rankins CSR Rating System

\begin{tabular}{|c|c|c|}
\hline \multicolumn{3}{|l|}{ Macrocosm } \\
\hline Item & NO & Sub-item \\
\hline \multirow{5}{*}{ Strategy } & M1 & Strategic CSR goals \\
\hline & M2 & $\begin{array}{l}\text { Sustainable development: the effects of climate change, } \\
\text { social problems, and the macro environment on the } \\
\text { sustainable development of companies }\end{array}$ \\
\hline & M3 & $\begin{array}{l}\text { Socially responsible strategies and corporations: the effects } \\
\text { of a company's provision of products and services on } \\
\text { society and the environment }\end{array}$ \\
\hline & M4 & $\begin{array}{l}\text { Announcement of sustainable development by the } \\
\text { management of companies }\end{array}$ \\
\hline & M5 & Planning corporate social responsibility goal \\
\hline \multirow{8}{*}{ Management } & M6 & Basic company information \\
\hline & M7 & A company's social responsibility values \\
\hline & M8 & $\begin{array}{l}\text { Existence of professional labor to monitor and supervise } \\
\text { CSR activities }\end{array}$ \\
\hline & M9 & $\begin{array}{l}\text { Methods and processes to manage environmental, } \\
\text { societal, and economic businesses }\end{array}$ \\
\hline & M10 & Disclosure system for company information \\
\hline & M11 & CSR-related risk assessment and management \\
\hline & M12 & Institutional norms for compliance of commercial morality \\
\hline & M13 & $\begin{array}{l}\text { Joint participation in CSR activities by related sub-divisions } \\
\text { and their subsidiaries }\end{array}$ \\
\hline \multirow{3}{*}{ Stakeholders } & M14 & Awareness about stakeholders and their importance \\
\hline & M15 & $\begin{array}{l}\text { Long-term communication with stakeholders and } \\
\text { improvement after receiving feedback }\end{array}$ \\
\hline & M16 & Evaluation of information by stakeholders \\
\hline \multicolumn{3}{|l|}{ Content } \\
\hline Item & NO & Sub-item \\
\hline \multirow{3}{*}{$\begin{array}{l}\text { Economic } \\
\text { Performance }\end{array}$} & $\mathrm{C} 1$ & $\begin{array}{l}\text { Financial information, such as annual sales, profits, and } \\
\text { dividends }\end{array}$ \\
\hline & $\mathrm{C} 2$ & Growth rates of sales, profits, and dividends \\
\hline & C3 & Sales of products and services, market share, innovativeness \\
\hline
\end{tabular}




\begin{tabular}{|c|c|c|}
\hline \multirow{7}{*}{$\begin{array}{l}\text { Employee rights/ } \\
\text { Human rights }\end{array}$} & $\mathrm{C} 4$ & Employees' composition: gender, age, total number \\
\hline & C5 & $\begin{array}{l}\text { Employees' education: total hours of education, number of } \\
\text { employees participating in education, number of lectures }\end{array}$ \\
\hline & C6 & $\begin{array}{l}\text { Safety production: healthcare program for employees, safe } \\
\text { working environment }\end{array}$ \\
\hline & $\mathrm{C} 7$ & $\begin{array}{l}\text { Human rights: same occupation-same pay, prohibition of } \\
\text { child labor, treatment for employee reporting }\end{array}$ \\
\hline & $\mathrm{C} 8$ & $\begin{array}{l}\text { Working environment: employee vacation, welfare and other } \\
\text { benefits, caring for employees }\end{array}$ \\
\hline & $\mathrm{C9}$ & $\begin{array}{l}\text { Union-related information, employee leisure activities, caring } \\
\text { for family members of employees, employee satisfaction } \\
\text { surveys }\end{array}$ \\
\hline & $\mathrm{C} 10$ & Company training and promotion of CSR knowledge \\
\hline \multirow{4}{*}{ Environment } & C11 & $\begin{array}{l}\text { Annual test results and certification of environmental } \\
\text { management systems, environmental protection investments } \\
\text { by year }\end{array}$ \\
\hline & $\mathrm{C} 12$ & $\begin{array}{l}\text { Awareness and prevention measures against environmental } \\
\text { pollution }\end{array}$ \\
\hline & $\mathrm{C} 13$ & $\begin{array}{l}\text { Identification of sources of energy and water, measurement } \\
\text { and recording of energy consumption, energy-saving } \\
\text { measures, and use of renewable energy }\end{array}$ \\
\hline & $\mathrm{C} 14$ & $\begin{array}{l}\text { Measurement and recording of carbon dioxide emissions, } \\
\text { preventive measures (for example, boiled drinking water) }\end{array}$ \\
\hline \multirow[b]{2}{*}{ Fair operation } & C15 & Preventive measures related to embezzlement \\
\hline & $\mathrm{C} 16$ & $\begin{array}{l}\text { Active promotion of CSR-related information to society as a } \\
\text { whole, overseeing the social responsibility of other social } \\
\text { groups }\end{array}$ \\
\hline \multirow{6}{*}{ Consumers } & $\mathrm{C} 17$ & $\begin{array}{l}\text { Quality assurance system for products and services of the } \\
\text { business, technical innovations }\end{array}$ \\
\hline & C18 & $\begin{array}{l}\text { Consumer (customer) relationship management system, } \\
\text { customer satisfaction surveys }\end{array}$ \\
\hline & C19 & Protection for the safety and health of the consumer \\
\hline & $\mathrm{C} 20$ & $\begin{array}{l}\text { Customer service convenience, customer reporting rates, } \\
\text { dispute settlement-related information }\end{array}$ \\
\hline & $\mathrm{C} 21$ & Protection of consumer privacy information \\
\hline & $\mathrm{C} 22$ & $\begin{array}{l}\text { Consumer education: the practice of educating consumers } \\
\text { about the dangers of the product }\end{array}$ \\
\hline
\end{tabular}




\begin{tabular}{|c|c|c|}
\hline \multirow{8}{*}{$\begin{array}{l}\text { Contribution to } \\
\text { social community } \\
\text { development }\end{array}$} & $\mathrm{C} 23$ & Amount of social donations \\
\hline & $\mathrm{C} 24$ & Employee volunteer activities \\
\hline & $\mathrm{C} 25$ & $\begin{array}{l}\text { Participation in the establishment of the regional policy and } \\
\text { industry standards }\end{array}$ \\
\hline & $\mathrm{C} 26$ & Job creation: annual employee recruitment \\
\hline & $\mathrm{C} 27$ & $\begin{array}{l}\text { Participation in science and technology projects in the region } \\
\text { and the country, contribution to the development of science } \\
\text { and technology }\end{array}$ \\
\hline & $\mathrm{C} 28$ & $\begin{array}{l}\text { Use of natural resources after receiving permission from the } \\
\text { local community, gathering opinions of local communities }\end{array}$ \\
\hline & $\mathrm{C} 29$ & $\begin{array}{l}\text { Promotion of health knowledge and improvement in disease } \\
\text { prevention awareness in the local community }\end{array}$ \\
\hline & C30 & $\begin{array}{l}\text { Consideration of the impact on the environment and local } \\
\text { communities when investment decisions are made }\end{array}$ \\
\hline \multicolumn{3}{|l|}{ Technique } \\
\hline \multirow{2}{*}{ Equity of contents } & $\mathrm{T} 1$ & Degree stated on all stakeholders related to CSR \\
\hline & $\mathrm{T} 2$ & Disclosure of the extent of negative information about CSR \\
\hline \multirow{2}{*}{$\begin{array}{l}\text { Consistency of } \\
\text { information }\end{array}$} & T3 & Consistency: consistency with previous reports \\
\hline & $\mathrm{T} 4$ & $\begin{array}{l}\text { Degree of the description related to the achievement of CSR } \\
\text { activities using data or ratio information }\end{array}$ \\
\hline \multirow{2}{*}{$\begin{array}{l}\text { Creativity of } \\
\text { reporting }\end{array}$} & T5 & Creativity of the structure and format for reporting \\
\hline & T6 & Impact of creativity on business efficiency \\
\hline \multirow{4}{*}{$\begin{array}{l}\text { Reliability/ } \\
\text { transparency }\end{array}$} & T7 & Degree of disclosure of stakeholders' opinions \\
\hline & T8 & Third party inspection \\
\hline & T9 & Authority of third party inspection agency \\
\hline & $\mathrm{T} 10$ & Efficiency in resolution of readers' opinion of the report \\
\hline \multirow{3}{*}{ Norms } & $\mathrm{T} 11$ & Policy norms of the report \\
\hline & T12 & Degree that the report criteria are met \\
\hline & T13 & Typographical errors made during preparation of the report \\
\hline \multirow{4}{*}{$\begin{array}{l}\text { Effectiveness of } \\
\text { information }\end{array}$} & T14 & Satisfaction of language version of the report \\
\hline & T15 & Accessible path of the report \\
\hline & $\mathrm{T} 16$ & $\begin{array}{l}\text { Improvement in disclosure effects given the design and } \\
\text { editing of the report }\end{array}$ \\
\hline & T17 & Table of related information, illustrated figures in the report \\
\hline
\end{tabular}


Table 4. CSR Score Trends of the Sample Companies

\begin{tabular}{|c|c|c|c|c|c|c|}
\hline \multirow{2}{*}{$\begin{array}{l}\text { Industry } \\
\text { classification }\end{array}$} & \multirow{2}{*}{ Exchange } & \multirow{2}{*}{ CSR } & \multicolumn{3}{|c|}{ Annual CSR score } & \multirow{2}{*}{ Average } \\
\hline & & & 2008 & 2009 & 2010 & \\
\hline \multirow{6}{*}{ Construction } & \multirow{3}{*}{ Shanghai } & mean & 25.00 & 25.26 & 30.07 & 26.77 \\
\hline & & $\max$ & 30.80 & 34.74 & 38.60 & 38.60 \\
\hline & & $\min$ & 19.93 & 17.92 & 17.23 & 17.23 \\
\hline & \multirow{3}{*}{ Shenzhen } & mean & 22.79 & 28.99 & 29.53 & 27.10 \\
\hline & & $\max$ & 23.35 & 29.35 & 32.41 & 32.41 \\
\hline & & $\min$ & 22.22 & 28.62 & 26.65 & 22.22 \\
\hline \multirow{6}{*}{ Mining } & \multirow{3}{*}{ Shanghai } & mean & 45.30 & 52.46 & 57.08 & 51.61 \\
\hline & & $\max$ & 68.76 & 78.49 & 80.29 & 80.29 \\
\hline & & $\min$ & 24.66 & 28.64 & 28.05 & 24.66 \\
\hline & \multirow{3}{*}{ Shenzhen } & mean & 29.17 & 27.46 & 30.26 & 28.96 \\
\hline & & $\max$ & 34.12 & 31.64 & 35.43 & 35.43 \\
\hline & & $\min$ & 24.23 & 24.29 & 26.16 & 24.23 \\
\hline \multirow{6}{*}{$\begin{array}{l}\text { Agriculture, } \\
\text { Forest, } \\
\text { Fishery }\end{array}$} & \multirow{3}{*}{ Shanghai } & mean & 20.85 & 23.71 & 20.06 & 21.54 \\
\hline & & $\max$ & 20.85 & 23.71 & 20.06 & 23.71 \\
\hline & & $\min$ & 20.85 & 23.71 & 20.06 & 20.06 \\
\hline & \multirow{3}{*}{ Shenzhen } & mean & 25.87 & 21.40 & 18.07 & 21.78 \\
\hline & & $\max$ & 25.87 & 21.40 & 18.07 & 25.87 \\
\hline & & $\min$ & 25.87 & 21.40 & 18.07 & 18.07 \\
\hline \multirow{6}{*}{ Wholesale, Retail } & \multirow{3}{*}{ Shanghai } & mean & 25.65 & 30.75 & 31.87 & 29.42 \\
\hline & & $\max$ & 35.86 & 45.77 & 43.97 & 45.77 \\
\hline & & $\min$ & 19.13 & 21.58 & 21.08 & 19.13 \\
\hline & \multirow{3}{*}{ Shenzhen } & mean & 27.13 & 29.13 & 33.09 & 29.78 \\
\hline & & $\max$ & 28.72 & 31.20 & 43.18 & 43.18 \\
\hline & & $\min$ & 26.12 & 26.48 & 25.14 & 25.14 \\
\hline \multirow{6}{*}{ Real estate, lease } & \multirow{3}{*}{ Shanghai } & mean & 24.10 & 27.94 & 28.20 & 26.74 \\
\hline & & $\max$ & 31.23 & 31.24 & 34.58 & 34.58 \\
\hline & & $\min$ & 15.56 & 21.77 & 23.49 & 15.56 \\
\hline & \multirow{3}{*}{ Shenzhen } & mean & 28.37 & 35.56 & 38.07 & 34.00 \\
\hline & & $\max$ & 36.30 & 71.06 & 71.87 & 71.87 \\
\hline & & $\min$ & 17.60 & 22.66 & 23.09 & 17.60 \\
\hline
\end{tabular}




\begin{tabular}{|c|c|c|c|c|c|c|}
\hline \multirow{6}{*}{ Service } & \multirow{3}{*}{ Shanghai } & mean & 28.38 & 30.62 & 31.06 & 30.02 \\
\hline & & $\max$ & 34.58 & 31.92 & 40.41 & 40.41 \\
\hline & & $\min$ & 17.29 & 28.29 & 22.33 & 17.29 \\
\hline & \multirow{3}{*}{ Shenzhen } & mean & 29.19 & 29.38 & 38.01 & 32.19 \\
\hline & & $\max$ & 36.79 & 40.42 & 52.36 & 52.36 \\
\hline & & $\min$ & 21.58 & 18.34 & 23.65 & 18.34 \\
\hline \multirow{6}{*}{$\begin{array}{l}\text { Entertainment, } \\
\text { culture }\end{array}$} & \multirow{3}{*}{ Shanghai } & mean & 22.57 & 19.76 & 24.92 & 22.42 \\
\hline & & $\max$ & 22.57 & 19.76 & 24.92 & 24.92 \\
\hline & & $\min$ & 22.57 & 19.76 & 24.92 & 19.76 \\
\hline & \multirow{3}{*}{ Shenzhen } & mean & 25.97 & 22.43 & 21.93 & 23.44 \\
\hline & & $\max$ & 25.97 & 22.43 & 21.93 & 25.97 \\
\hline & & $\min$ & 25.97 & 22.43 & 21.93 & 21.93 \\
\hline \multirow{6}{*}{ Transportation } & \multirow{3}{*}{ Shanghai } & mean & 33.30 & 36.69 & 40.47 & 36.82 \\
\hline & & $\max$ & 61.73 & 66.91 & 77.59 & 77.59 \\
\hline & & $\min$ & 15.82 & 21.20 & 21.97 & 15.82 \\
\hline & \multirow{3}{*}{ Shenzhen } & mean & 28.86 & 37.22 & 38.52 & 34.86 \\
\hline & & $\max$ & 34.54 & 38.05 & 39.51 & 39.51 \\
\hline & & $\min$ & 23.17 & 36.39 & 37.52 & 23.17 \\
\hline \multirow{6}{*}{$\begin{array}{l}\text { Electricity, gas, } \\
\text { utilities }\end{array}$} & \multirow{3}{*}{ Shanghai } & mean & 29.48 & 32.59 & 33.06 & 31.71 \\
\hline & & $\max$ & 39.64 & 44.84 & 46.66 & 46.66 \\
\hline & & $\min$ & 22.94 & 25.21 & 23.23 & 22.94 \\
\hline & \multirow{3}{*}{ Shenzhen } & mean & 36.73 & 35.99 & 39.24 & 37.32 \\
\hline & & $\max$ & 52.89 & 55.69 & 62.51 & 62.51 \\
\hline & & $\min$ & 28.70 & 23.68 & 20.96 & 20.96 \\
\hline \multirow{6}{*}{ Manufacturing } & \multirow{3}{*}{ Shanghai } & mean & 27.88 & 30.19 & 31.56 & 29.88 \\
\hline & & $\max$ & 65.12 & 76.14 & 78.44 & 78.44 \\
\hline & & $\min$ & 15.20 & 15.32 & 17.21 & 15.20 \\
\hline & \multirow{3}{*}{ Shenzhen } & mean & 28.76 & 32.16 & 34.33 & 31.75 \\
\hline & & $\max$ & 60.69 & 64.15 & 71.50 & 71.50 \\
\hline & & $\min$ & 20.42 & 21.75 & 18.77 & 18.77 \\
\hline \multirow{6}{*}{ General } & \multirow{3}{*}{ Shanghai } & mean & 22.92 & 22.53 & 23.00 & 22.82 \\
\hline & & $\max$ & 29.03 & 26.98 & 28.00 & 29.03 \\
\hline & & $\min$ & 18.61 & 17.22 & 16.12 & 16.12 \\
\hline & \multirow{3}{*}{ Shenzhen } & mean & 23.87 & 23.32 & 24.79 & 24.00 \\
\hline & & $\max$ & 27.97 & 31.21 & 32.33 & 32.33 \\
\hline & & $\min$ & 18.20 & 16.62 & 20.18 & 16.62 \\
\hline
\end{tabular}




\begin{tabular}{l|c|c|c|c|c|c}
\hline & \multirow{3}{*}{ Shanghai } & $\operatorname{mean}$ & 26.05 & 30.09 & 32.47 & 29.54 \\
\cline { 3 - 7 } & & $\max$ & 40.85 & 44.33 & 56.15 & 56.15 \\
\cline { 3 - 7 } Telecommunication & $\min$ & 17.33 & 18.45 & 18.52 & 17.33 \\
\cline { 3 - 7 } & \multirow{3}{*}{ Shenzhen } & $\operatorname{mean}$ & 26.36 & 31.67 & 39.73 & 32.59 \\
\cline { 3 - 7 } & & $\max$ & 34.26 & 46.58 & 70.46 & 70.46 \\
\cline { 3 - 7 } & $\min$ & 18.86 & 23.00 & 28.23 & 18.86 \\
\hline \multicolumn{2}{l|l}{ Total average score } & & 28.79 & 31.80 & 33.93 & 31.51 \\
\hline \multicolumn{2}{l|l}{ Total max score } & & 68.76 & 78.49 & 80.29 & 80.29 \\
\hline \multicolumn{2}{l|l}{ Total min score } & & 15.20 & 15.32 & 16.12 & 15.20 \\
\hline
\end{tabular}

\section{Regression analyses}

Waddock and Graves (1997) argue that a two-way analysis between two variables is essential to understand the relevance of CSR and financial performance. Before verifying the impact of CSR activities on firm value, a causality test between CSR and firm value is conducted to determine whether CSR activities increase firm value $(<$ Eq. $1>$ ) or whether initially high-value firms actively perform CSR activities $(<$ Eq. $2>$ ).

Based on the panel data analysis, we first use $<$ Eq. $1>,<$ Eq. $2>$ to perform the causality validation

$$
\begin{aligned}
& \text { Value }_{i t}=\sum_{i=1}^{n} \alpha_{i} \text { CSR }_{t-1}+\sum_{i=1}^{n} \beta_{i} \text { Value }_{t-1}+u_{i t} \\
& \text { CSR }_{i t}=\sum_{i=1}^{n} \gamma_{i} \text { CSR }_{i t-1}+\sum_{i=1}^{n} \delta_{i} \text { Value }_{i t-1}+u_{i t}
\end{aligned}
$$

We also use panel analysis with $<$ Eq. $3>$ to analyze the effects of CSR on corporate value.

$$
\begin{aligned}
\text { Value }_{i t}= & \beta_{0}+\beta_{1} \operatorname{CSR}_{i t-1}+\beta_{2} \text { SIZE }_{i t-1}+\beta_{3} \text { EPS }_{i t-1}+\beta_{4} L E V_{i t-1}+ \\
& \beta_{5} G R W_{i t-1}+\epsilon_{i t}
\end{aligned}
$$

Next, we set $<$ Eq. $4>$ by adding 10 corporate governance variables in turn to evaluate their interaction effects with CSR.

$$
\begin{aligned}
\text { Value }_{i t}= & \beta_{0}+\beta_{1} C_{S S R_{i t-1}+\beta_{2} C G_{j}+\beta_{3} C G_{j} \times C S R_{i t-1}+\beta_{4} S I Z E_{i t-1}+} \\
& \beta_{6} L E V_{i t-1}+\beta_{7} G R W_{i t-1}+\epsilon_{i t} \text { where } 1 \leq j \leq 10 \quad<\text { Eq. } 4>
\end{aligned}
$$


Using $<$ Eq. 4>, we carry out panel analysis using 10 corporate governance variables, respectively. First, those governance variables are divided into two groups accordingly based on the level of the corporate governance variables (see $<$ Table 10 $>$ ). Second, regression analysis is performed for each group to determine the impact of CSR activities on firm value, which might appear differently depending on the value of the governance variables.

$$
\begin{aligned}
\text { Value }_{i t}= & \beta_{0}+\beta_{1} \operatorname{CSR}_{i t-1}+\beta_{2} \operatorname{SIZE}_{i t-1}+\beta_{3} \text { EPS }_{i t-1}+\beta_{4} L E V_{i t-1}+ \\
& \beta_{5} G R W_{i t-1}+\epsilon_{i t}
\end{aligned}
$$

Finally, after analyzing the impact of CSR on firm value in accordance with the corporate governance variables, we perform a panel analysis using $\langle$ Eq. $6>$ to test whether a company more actively engages in CSR activities under certain levels of corporate governance.

$$
\begin{aligned}
& \operatorname{CSR}_{i t}=\beta_{0}+\beta_{1} \operatorname{CR}_{i t-1}+\beta_{2} Z_{i t-1}+\beta_{3} \text { managheshr }_{i t-1}+\beta_{4} \text { directshr }_{i t-1}+ \\
& \beta_{5} \text { Supervisorshr }_{i t-1}+\beta_{6} P_{i t-1}+\beta_{7} \text { DSize }_{i t-1}+\beta_{8} \text { SSize }_{i t-1}+ \\
& \beta_{9} \text { Indep_ratio }_{i t-1}+ \\
& <\text { Eq. 6> }
\end{aligned}
$$

\section{RESULTS}

\section{Descriptive statistics}

Table 5. Descriptive Statistics

\begin{tabular}{l|c|c|l|l|l|c}
\hline Variables & $\mathrm{N}$ & \multicolumn{1}{c|}{ mean } & \multicolumn{1}{c|}{$\max$} & \multicolumn{1}{c|}{$\min$} & \multicolumn{1}{c}{ median } & \multicolumn{1}{c}{ std. dev. } \\
\hline Value & 831 & 1.8035769 & 15.1134 & 0.652 & 1.4785 & 1.1295604 \\
\hline CSR & 831 & 31.507485 & 80.29 & 15.2 & 28.54 & 11.2364462 \\
\hline CR1 & 831 & 0.3922908 & 0.8641884 & 0.0369 & 0.4007 & 0.1626508 \\
\hline$z$ & 831 & 17.96826 & 274.76 & 1 & 8.0912162 & 26.4910084 \\
\hline manageshr & 831 & 0.0254095 & 0.735 & 0 & 0.00003478 & 0.0985377 \\
\hline directshr & 831 & 0.0231819 & 0.654 & 0 & $6.56 \mathrm{E}-06$ & 0.0921568 \\
\hline supervisorshr & 831 & 0.0014037 & 0.1425 & 0 & 0 & 0.0101306 \\
\hline
\end{tabular}




\begin{tabular}{l|l|l|l|l|l|l}
\hline $\mathrm{P}$ & 831 & 0.2599278 & 1 & 0 & 0 & 0.4388589 \\
\hline dsize & 831 & 6.1528279 & 13 & 1 & 6 & 1.5874473 \\
\hline ssize & 831 & 4.2069795 & 11 & 2 & 3 & 1.483402 \\
\hline Indep_ratio & 831 & 0.3648037 & 0.6 & 0 & 0.3333333 & 0.0592038 \\
\hline stateowner & 831 & 0.7256318 & 1 & 0 & 1 & 0.4464641 \\
\hline SIZE & 831 & 22.670242 & 28.1356484 & 19.662737 & 22.5194142 & 1.415356 \\
\hline EPS & 831 & 0.4791692 & 5.8932 & -2.22 & 0.3597 & 0.5606302 \\
\hline LEV & 831 & 1.3818031 & 10.8824438 & -2.1862569 & 1.0644229 & 1.1045665 \\
\hline GRW & 831 & 0.2410588 & 10.5916814 & -0.722847 & 0.1523273 & 0.5755948 \\
\hline
\end{tabular}

The basic statistics of the key variables are as follows: the average largest shareholder stake is $39.2 \%$, its maximum value is $86.4 \%$, and a multiple of the $\mathrm{Z}$ indexdefined as the largest shareholder stake divided by the second largest shareholder stake - is more than a maximum of 200 times and on average 18 times, which indicates a significant ownership concentration in the Chinese company companies. Before the regression analysis, the existence of a multicollinearity problem between variables should be checked to ensure that the results of the panel analysis are valid. The multicollinearity test result is shown in $<$ Table $6>, 5$ which indicates that no strong correlation was found when the controlled variables were excluded. This result implies that this empirical study is immune to the multicollinearity problem.

\section{Impact of corporate social responsibility activities on firm value}

Before investigating the impact of CSR activities on firm value, we conduct a causality test between CSR activities and firm value. Conversely, we investigate whether the previous year's CSR causes (or precedes) this year's firm value, or vice versa. As shown in $\langle$ Table $7>$, a causal relationship may exist between CSR and corporate values; in particular, CSR precedes firm value. However, because firm value may precede CSR with simultaneous weak significance, a robustness check using an instrumental variable should be further conducted.

5. Based on the value of variable inflation factors (VIFs), the directors' ownership variable is dropped because of its high correlation with management ownership. All other variables have VIFs less than 2. Therefore, Hypothesis 2-4 is automatically dropped. 


\begin{tabular}{|c|c|c|c|c|c|c|c|c|c|c|c|c|c|c|c|c|c|c|c|c|c|c|c|}
\hline य & & & & & & & & & & & & & & & & & & & & & & 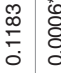 & \\
\hline $\begin{array}{l}0 \\
\text { I } \\
\text { }\end{array}$ & & & & & & & & & & & & & & & & & & & & $\begin{array}{l}\mathscr{0} \\
0 \\
0 \\
0 \\
i\end{array}$ & 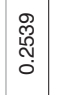 & 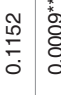 & \\
\hline$\frac{山}{\omega}$ & & & & & & & & & & & & & & & & & & & $\begin{array}{l}\hat{\circ} \\
\stackrel{\circ}{0}\end{array}$ & 离 & 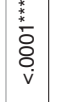 & 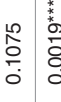 & \\
\hline 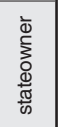 & & & & & & & & & & & & & & & & & $\frac{m}{\stackrel{m}{m}}$ & 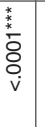 & & $\begin{array}{l}: \\
: \\
\stackrel{0}{0} \\
\end{array}$ & $\begin{array}{l}f \\
\vdots \\
o \\
v \\
v\end{array}$ & 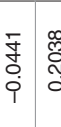 & \\
\hline $\begin{array}{l}\frac{0}{0} \\
\frac{0}{0} \\
\end{array}$ & & & & & & & & & & & & & & & 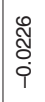 & 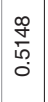 & 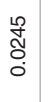 & 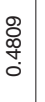 & 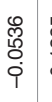 & $\begin{array}{l}\mathscr{0} \\
0 \\
0 \\
\end{array}$ & 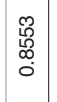 & 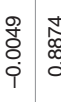 & \\
\hline$\stackrel{\stackrel{N}{\mathscr{W}}}{\stackrel{\mathscr{W}}{6}}$ & & & & & & & & & & & & & $\frac{\hat{\infty}}{\frac{0}{0}}$ & $\begin{array}{l}i \\
0 \\
8 \\
8 \\
0 \\
0\end{array}$ & 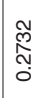 & 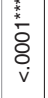 & 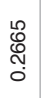 & 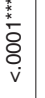 & $\begin{array}{l}\hat{\alpha} \\
0 \\
0 \\
0\end{array}$ & $\mid \begin{array}{l}0 \\
0 \\
0 \\
0 \\
\end{array}$ & 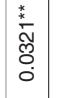 & 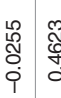 & \\
\hline$\frac{\mathbb{N}}{\frac{N}{8}}$ & & & & & & & & & & & \begin{tabular}{l}
0 \\
\multirow{J}{*}{} \\
0 \\
0
\end{tabular} & $\bar{o}_{\mathrm{g}}$ & 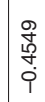 & 素 & 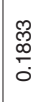 & 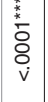 & 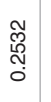 & 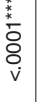 & $\begin{array}{l}\frac{\pi}{\sigma} \\
\stackrel{c}{0} \\
0\end{array}$ & $\mid \begin{array}{l}\infty \\
o \\
0 \\
0 \\
0\end{array}$ & 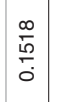 & 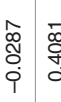 & \\
\hline a & & & & & & & & & & 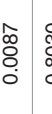 & $\mid \begin{array}{l}\infty \\
\infty \\
0 \\
0 \\
0\end{array}$ & 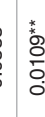 & $\begin{array}{l}\infty \\
0 \\
0 \\
\dot{0} \\
\dot{i}\end{array}$ & $\frac{N}{\frac{N}{n}} \frac{0}{0}$ & \begin{tabular}{|l}
$\infty$ \\
$\stackrel{\infty}{0}$ \\
\\
0 \\
0
\end{tabular} & 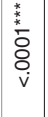 & 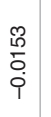 & $\begin{array}{l}: \\
: \\
0 \\
0\end{array}$ & 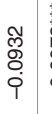 & 定 & $\begin{array}{l}\mathfrak{D} \\
\hat{N} \\
0 \\
0\end{array}$ & \begin{tabular}{l|l} 
& 0 \\
0 & 0 \\
0 & 0 \\
$\dagger$ & 0
\end{tabular} & \\
\hline 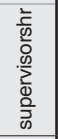 & & & & & & & & 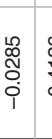 & \begin{tabular}{l|l}
0 \\
$\frac{N}{4}$ \\
0 \\
0
\end{tabular} & 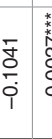 & 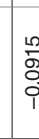 & $\vec{b}$ & 岕 & 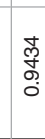 & 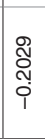 & 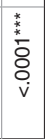 & $\begin{array}{l}\text { v } \\
\overline{0} \\
\dot{T}\end{array}$ & $\begin{array}{l}0 \\
0 \\
0 \\
0 \\
0 \\
0\end{array}$ & \begin{tabular}{l|l} 
芯 \\
0 \\
0 \\
0
\end{tabular} & $\mid \begin{array}{l}0 \\
0 \\
0 \\
0 \\
0 \\
i\end{array}$ & 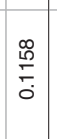 & \begin{tabular}{ll|l}
0 & $\delta$ \\
0 \\
0 \\
0
\end{tabular} & \\
\hline 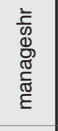 & & & & & & $\begin{array}{l}\text { 品 } \\
\stackrel{\leftrightarrow}{0} \\
\text { O }\end{array}$ & 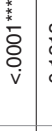 & $\begin{array}{c}\frac{m}{v} \\
\stackrel{i}{q} \\
\dot{q}\end{array}$ & 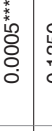 & 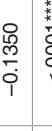 & 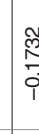 & 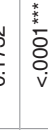 & $\begin{array}{l}8 \\
0 \\
0 \\
0\end{array}$ & $\begin{array}{l}L \\
0 \\
0 \\
0 \\
0\end{array}$ & 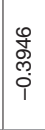 & $\begin{array}{l}\frac{1}{2} \\
\overline{8} \\
\dot{0} \\
\dot{v}\end{array}$ & $\begin{array}{c}\underset{\tilde{N}}{N} \\
\stackrel{i}{0}\end{array}$ & $\begin{array}{l}* \\
\stackrel{*}{*} \\
\text { o } \\
\mathrm{v} \\
\mathrm{v}\end{array}$ & 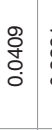 & $\begin{array}{l}\text { 足 } \\
0 \\
0 \\
\end{array}$ & $\begin{array}{l}0 \\
\vdots \\
8 \\
8 \\
0 \\
0\end{array}$ & \begin{tabular}{l|l}
$\bar{\delta}$ & $\alpha$ \\
0 \\
0 \\
0
\end{tabular} & \\
\hline$N$ & & & & 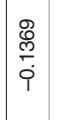 & 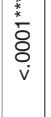 & $\begin{array}{l}\hat{N} \\
\hat{O} \\
0 \\
i\end{array}$ & 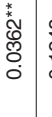 & 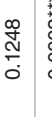 & 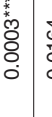 & $\begin{array}{ll}\vdots \\
\vdots \\
0 \\
\vdots \\
i\end{array}$ & 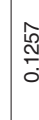 & 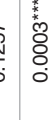 & 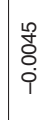 & 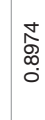 & $\begin{array}{l}\hat{\Xi} \\
\bar{\sigma} \\
\end{array}$ & 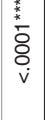 & $\begin{array}{l}\text { 苋 } \\
\text { Oे } \\
0\end{array}$ & 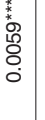 & $\begin{array}{l}\hat{8} \\
\text { o. } \\
\text { i } \\
\text { i }\end{array}$ & 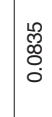 & $\begin{array}{l}\frac{*}{2} \\
0 \\
0 \\
0 \\
0\end{array}$ & 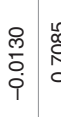 & \\
\hline$\overline{\tilde{d}}$ & & 离 & 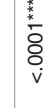 & $\begin{array}{l}0 \\
\stackrel{0}{0} \\
\grave{i}\end{array}$ & 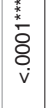 & $\begin{array}{l}\tilde{\infty} \\
\stackrel{0}{0} \\
0 \\
i \\
1\end{array}$ & 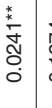 & $\begin{array}{c}\stackrel{+}{N} \\
\stackrel{N}{0}\end{array}$ & סֵ & 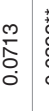 & 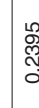 & 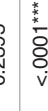 & $\begin{array}{l}\text { O্. } \\
\text { Oे } \\
0\end{array}$ & $\begin{array}{l}\text { 畩 } \\
\text { ơ }\end{array}$ & 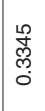 & $\begin{array}{l}\stackrel{*}{*} \\
\stackrel{8}{8} \\
\dot{v} \\
\dot{v}\end{array}$ & $\begin{array}{c}\stackrel{\circ}{o} \\
\stackrel{o}{0} \\
\circ\end{array}$ & 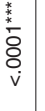 & $\begin{array}{l}0 \\
0 \\
\vdots \\
0 \\
0\end{array}$ & $\begin{array}{l}\text { on } \\
0 \\
0 \\
0 \\
0\end{array}$ & $\begin{array}{l}\mathcal{g} \\
\stackrel{g}{0} \\
\dot{0}\end{array}$ & 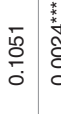 & \\
\hline $\begin{array}{l}\frac{r}{0} \\
0 \\
0\end{array}$ & \begin{tabular}{l}
$\bar{S}$ \\
\multirow{N}{N}{} \\
$\stackrel{0}{0}$
\end{tabular} & 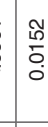 & 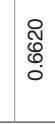 & 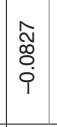 & \begin{tabular}{l}
$*$ \\
\multirow{2}{*}{} \\
$\stackrel{2}{0}$ \\
0 \\
0 \\
\end{tabular} & 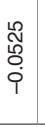 & $\begin{array}{l}0 \\
\stackrel{0}{0} \\
0 \\
0\end{array}$ & 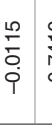 & 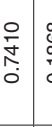 & $\begin{array}{l}\infty \\
\stackrel{\circ}{\infty} \\
\\
\end{array}$ & $\frac{9}{9}$ & $\begin{array}{l}* \\
\stackrel{*}{\circ} \\
\mathrm{v}\end{array}$ & $\begin{array}{l}\text { 㟔 } \\
\text { ô } \\
\dot{\varphi}\end{array}$ & $\begin{array}{l}\text { so } \\
\text { o } \\
0 \\
0\end{array}$ & 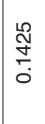 & 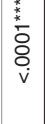 & $\begin{array}{l}\hat{f} \\
\text { ơ } \\
0\end{array}$ & 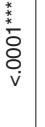 & 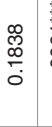 & $\begin{array}{l}\hat{a} \\
\text { d. } \\
0\end{array}$ & 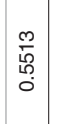 & 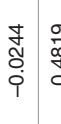 & \\
\hline & $\overline{\mathrm{d}}$ & & N & 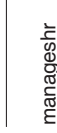 & שֶ. & 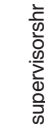 & & 0 & & $\frac{\mathbb{N}}{\frac{\pi}{0}}$ & & 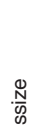 & 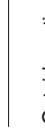 & 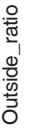 & 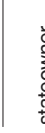 & 竒 & $\frac{\mathrm{N}}{\omega}$ & & $\begin{array}{l}\infty \\
\frac{1}{4}\end{array}$ & 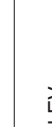 & 䇋 & 㑔 & \\
\hline
\end{tabular}


Table 7. Causality Test

\begin{tabular}{c|c|c|c}
\hline \multicolumn{4}{c}{ Causality Wald Test } \\
\hline Causality direction & Chi-square & $\operatorname{Pr}>$ Chi-sq & Hypothesis \\
\hline CSR $\rightarrow$ Value & 20.12 & $<.0001^{\star \star *}$ & H0: CSR does not cause value \\
\hline Value $\rightarrow$ CSR & 3.34 & $0.0675^{\star}$ & H0: Value does not cause CSR \\
\hline
\end{tabular}

$<$ Table $8>$ indicates the fixed effect controlled results from an investigation into how CSR affects firm value. Initially, both the fixed effect and the random effect models are considered. The fixed effect model is selected with statistically significant parameters using the Hausman specification. Panel analysis of the entire sample shows that a relationship exists between CSR activities of the previous year and this year's firm value at a $1 \%$ significance level, after controlling for various variables. In addition, as a control variable, larger firm size and earnings per share indicate higher firm values. A higher debt ratio indicates a larger firm value, and a lower growth rate of total assets leads to a larger firm value. The result of an analysis that separates companies listed on the Shanghai Stock Exchange and on the Shenzhen Stock Exchange is consistent with the results for the entire sample.

Table 8. CSR and Firm Value

Dept. variable: Tobin's $Q$, Indep. Variable: CSR. Value $_{t}=\beta_{0}+\beta_{1}$ CSR $_{t-1}+\beta_{2} \operatorname{SIZE}_{t-1}+\beta_{3}$ EPS $_{t-1 \beta_{2}}+\beta_{4} L E V_{t-1}+\beta_{5} G R W_{t-1}+\epsilon_{t}$

\begin{tabular}{|c|c|c|c|c|c|c|c|c|c|c|c|c|}
\hline \multirow[b]{2}{*}{ Variables } & \multicolumn{4}{|c|}{ All sample } & \multicolumn{4}{|c|}{ Shanghai Exchange } & \multicolumn{4}{|c|}{ Shenzhen Exchange } \\
\hline & Coeff. & Std. dev. & t-value & $p$-value & Coeff. & Std. dev. & t-value & $\mathrm{p}$-value & Coeff. & Std. dev. & t-value & $\mathrm{p}$-value \\
\hline Const. & -20.38 & 4.02 & -5.07 & $<.0001$ & -19.37 & 5.39 & -3.6 & 0.0004 & -14.61 & 4.86 & -3.01 & 0.003 \\
\hline CSR & 0.02 & 0.01 & 2.68 & $0.0076^{\star \star \star}$ & 0.02 & 0.01 & 1.96 & $0.051^{\star}$ & 0.02 & 0.01 & 1.86 & $0.0637^{\star}$ \\
\hline SIZE & 0.81 & 0.16 & 5.03 & $<.0001^{\star \star \star}$ & 0.77 & 0.22 & 3.56 & $0.0004^{\star \star \star}$ & 0.81 & 0.24 & 3.33 & $0.001^{\star \star \star}$ \\
\hline EPS & 0.02 & 0.10 & 0.22 & 0.8296 & 0.01 & 0.13 & 0.11 & 0.9135 & 0.06 & 0.16 & 0.37 & 0.7098 \\
\hline LEV & -0.15 & 0.08 & -1.95 & $0.0515^{\star}$ & -0.15 & 0.10 & -1.44 & 0.1508 & -0.10 & 0.16 & -0.63 & 0.5318 \\
\hline GRW & -0.11 & 0.07 & -1.71 & $0.0887^{*}$ & -0.09 & 0.13 & -0.7 & 0.4844 & -0.12 & 0.07 & -1.68 & $0.0948^{*}$ \\
\hline F-value & \multicolumn{4}{|c|}{2.56} & \multicolumn{4}{|c|}{2.28} & \multicolumn{4}{|c|}{3.05} \\
\hline$R^{2}$ & \multicolumn{4}{|c|}{0.6397} & \multicolumn{4}{|c|}{0.6878} & \multicolumn{4}{|c|}{0.6878} \\
\hline $\mathrm{N}$ & \multicolumn{4}{|c|}{277} & \multicolumn{4}{|c|}{176} & \multicolumn{4}{|c|}{101} \\
\hline $\begin{array}{l}\text { Time } \\
\text { series }\end{array}$ & \multicolumn{4}{|c|}{3} & \multicolumn{4}{|c|}{3} & \multicolumn{4}{|c|}{3} \\
\hline Model & \multicolumn{4}{|c|}{ fixed effect } & \multicolumn{4}{|c|}{ fixed effect } & \multicolumn{4}{|c|}{ fixed effect } \\
\hline
\end{tabular}

Notes: *, ${ }^{* *}$, and ${ }^{* * *}$ represent $10 \%, 5 \%$, and $1 \%$ significance levels, respectively. 


\section{Effects of corporate social responsibility on firm value depending on corporate governance structure}

In the previous analysis, we verify that a corporation can increase its corporate value through CSR activities. Furthermore, for different corporate governance/ownership structures, to verify how the effects of these variables differ, panel analysis using such governance variables as interaction terms is performed.

$<$ Table 9> indicates the regression results using nine corporate governance variables, each performed by adopting fixed effects panel analysis using the Tobin's Q dependent variable.

The interaction terms between the corporate governance variables and CSR (CG $\times$ CSR) show significant negative coefficients in Eq. (1) and Eq. (8). Conversely, CSR has a weaker impact on corporate value because the largest shareholder stake appears at a higher governance level and for a higher proportion of outside directors. Namely, the effect of CSR on firm value weakens as the levels of the two corporate governance variables increase. The interaction terms of the other equations are not statistically significant. Accordingly, inferring that a firm's largest shareholder uses CSR more to obtain private benefits than for the interest of shareholders is possible. Outside directors, who may not be independent given the nature of Chinese companies, are interpreted as not properly checking CSR activities, thus leading to weaker effects on firm value.

Depending on the level of corporate governance, similar panel analysis using the separation of two groups should be performed. $<$ Table $10>$ presents criteria for the corporate governance variables divided into two groups. Group A has an above average governance structure and Group B has a below average governance structure.

$<$ Table 11> shows the results of the group panel analysis. For group A, CSRs in regressions (3), (4), (5), (7), (8), and (10) have positive effects on firm value at the 5\% significance level. However, the results were not statistically significant in regressions (1), (2), (6), and (9). For Group B, CSRs have positive effects on firm values at a 5\% significance level in regressions (1), (2), (6), and (9). In regressions (3), (4), (5), (7), (8), and (10), the results were not statistically significant. According to regression (1), CSR activities have positive effects on firm values in group B, which has a relatively lower largest shareholder stake. However, CSR does not have a significant effect in group A, which has a relatively higher largest shareholder stake. In regression (2), CSRs have positive effects on firm values in group B, which has a lower largest shareholder stake relative to the second largest shareholder stake. However, CSRs do not have significant effects on firm value in group $\mathrm{A}$, which has a higher largest shareholder stake relative to the second largest shareholder stake. In regressions (3), (4), 
and (5), CSR has a significant effect on firm value when executive ownership is high, director ownership is high, and audit committee ownership is high. In contrast, CSR does not have a significant effect on firm value when executive ownership is low, director ownership is low, and audit committee ownership is low. In regression (6), CSR increases firm value when the chairman of the board and the CEO are not the same person. When the chairman of the board and the CEO are the same person, CSR does not have significant effects. In regressions (7) and (8), CSR increases firm value when the board of directors and the audit committee are relatively large. However, CSR does not have significant effects when the board and the audit committee are relatively small. In regression (10), CSR increases corporate value when the percentage of outside directors is relatively low. However, CSR does not have significant effects on firm value when the percentage of outside directors is relatively high. Finally, in regression (10), CSR increases firm value when the largest shareholder is the country government. When the largest shareholder is not the country, CSR does not significantly influence firm value. These results are in accordance with the argument proposed initially that the effects of CSR activities on firm value are different depending on the level of corporate governance, thus supporting Hypothesis 2. Conversely, CSR activities have a positive effect on firm value for a relatively low level of the largest shareholder ownership and a relatively high level of audit committee ownership. Furthermore, similar to most companies in the United States, CSR activities positively affect firm value through a supervising role that is faithfully performed if the CEO and chairman of the board are different individuals and if the board of directors and the audit committee are large. In contrast, the role of independent directors in China appears to be dysfunctional. If the country is the company's largest shareholder, it pursues CSR activities from the perspective of its economic and social policy dimension. As a result, CSR has a positive effect on firm value. These results suggest that agency costs are present during the process of implementing CSR activities. 


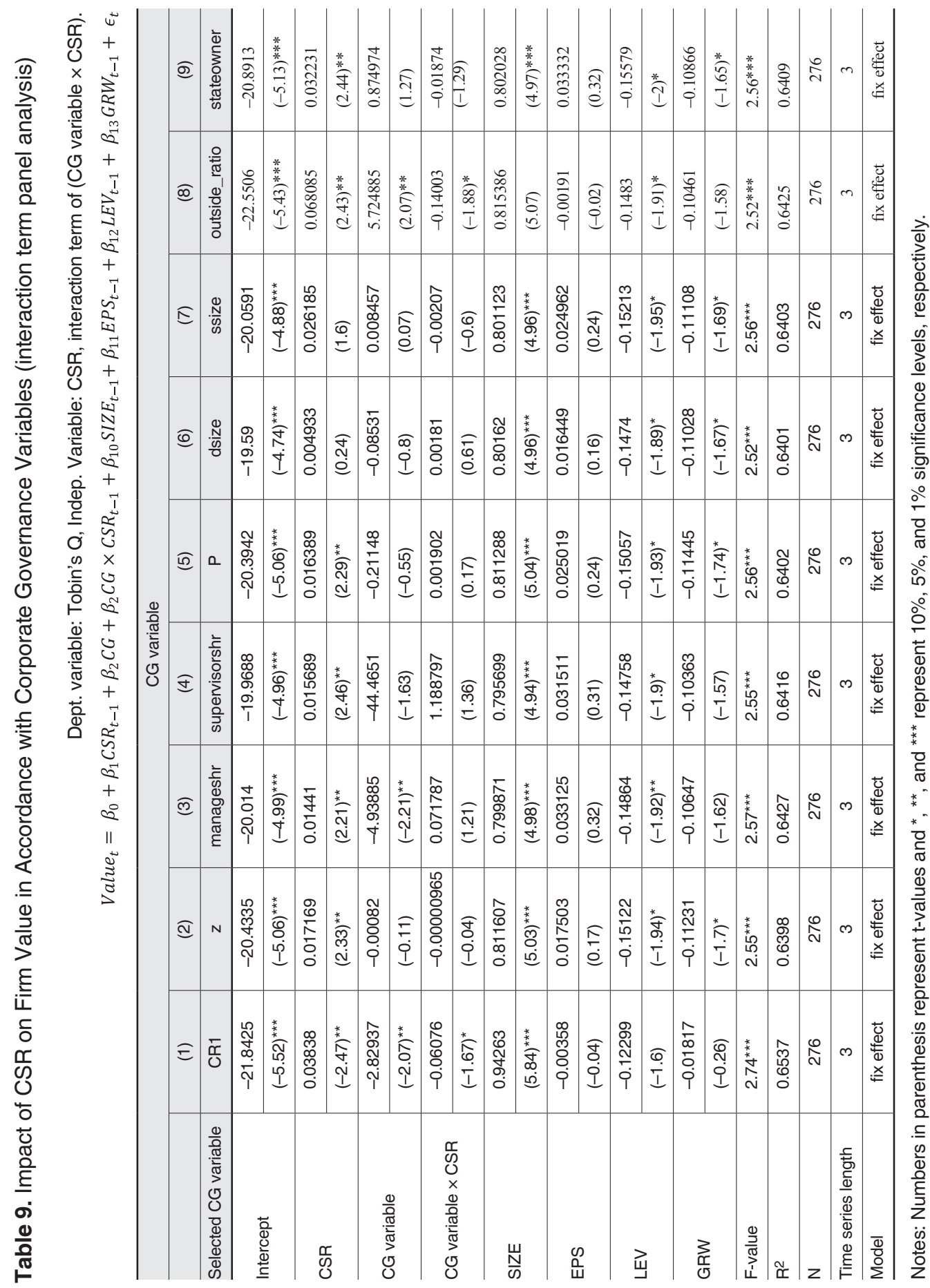


Table 10. Criteria for Group Division

\begin{tabular}{|c|c|c|c|c|c|c|}
\hline & \multicolumn{3}{|c|}{ Group A } & \multicolumn{3}{|c|}{ Group B } \\
\hline Variables & Criteria & Description & $\mathrm{N}$ & Criteria & Description & $\mathrm{N}$ \\
\hline CR1 & $\begin{array}{l}\text { Above } \\
\text { median }\end{array}$ & $\begin{array}{c}\text { Largest } \\
\text { shareholder's } \\
\text { holding } \geq 40 \%\end{array}$ & 417 & $\begin{array}{l}\text { Below } \\
\text { median }\end{array}$ & $\begin{array}{c}\text { Largest } \\
\text { shareholder's } \\
\text { holding }<40 \%\end{array}$ & 414 \\
\hline z & $\begin{array}{l}\text { Above } \\
\text { median }\end{array}$ & $\geq 8.09$ & 416 & $\begin{array}{l}\text { Below } \\
\text { median }\end{array}$ & $<8.22$ & 415 \\
\hline manageshr & $\begin{array}{l}\text { Above } \\
\text { median }\end{array}$ & $\geq 0.0034 \%$ & 418 & $\begin{array}{l}\text { Below } \\
\text { median }\end{array}$ & $<0.0034 \%$ & 413 \\
\hline supervisorshr & $>0$ & & 324 & $=0$ & & 507 \\
\hline$P$ & $=1$ & $\begin{array}{c}\text { CEO and } \\
\text { chairperson are the } \\
\text { same }\end{array}$ & 216 & $=0$ & $\begin{array}{c}\text { CEO and } \\
\text { chairperson are } \\
\text { not the same }\end{array}$ & 615 \\
\hline dsize & $\begin{array}{l}\text { Above } \\
\text { median }\end{array}$ & $\geq 7$ & 254 & $\begin{array}{l}\text { Below } \\
\text { median }\end{array}$ & $\leq 6$ & 577 \\
\hline ssize & $\begin{array}{l}\text { Above } \\
\text { median }\end{array}$ & $\geq 4$ & 403 & $\begin{array}{l}\text { Below } \\
\text { median }\end{array}$ & $\leq 3$ & 428 \\
\hline outside_ratio & $\begin{array}{l}\text { Above } \\
\text { median }\end{array}$ & $\geq 35 \%$ & 402 & $\begin{array}{l}\text { Below } \\
\text { median }\end{array}$ & $<35 \%$ & 429 \\
\hline stateowner & $=1$ & State-owned & 603 & $=0$ & $\begin{array}{c}\text { Privately- } \\
\text { owned }\end{array}$ & 228 \\
\hline
\end{tabular}




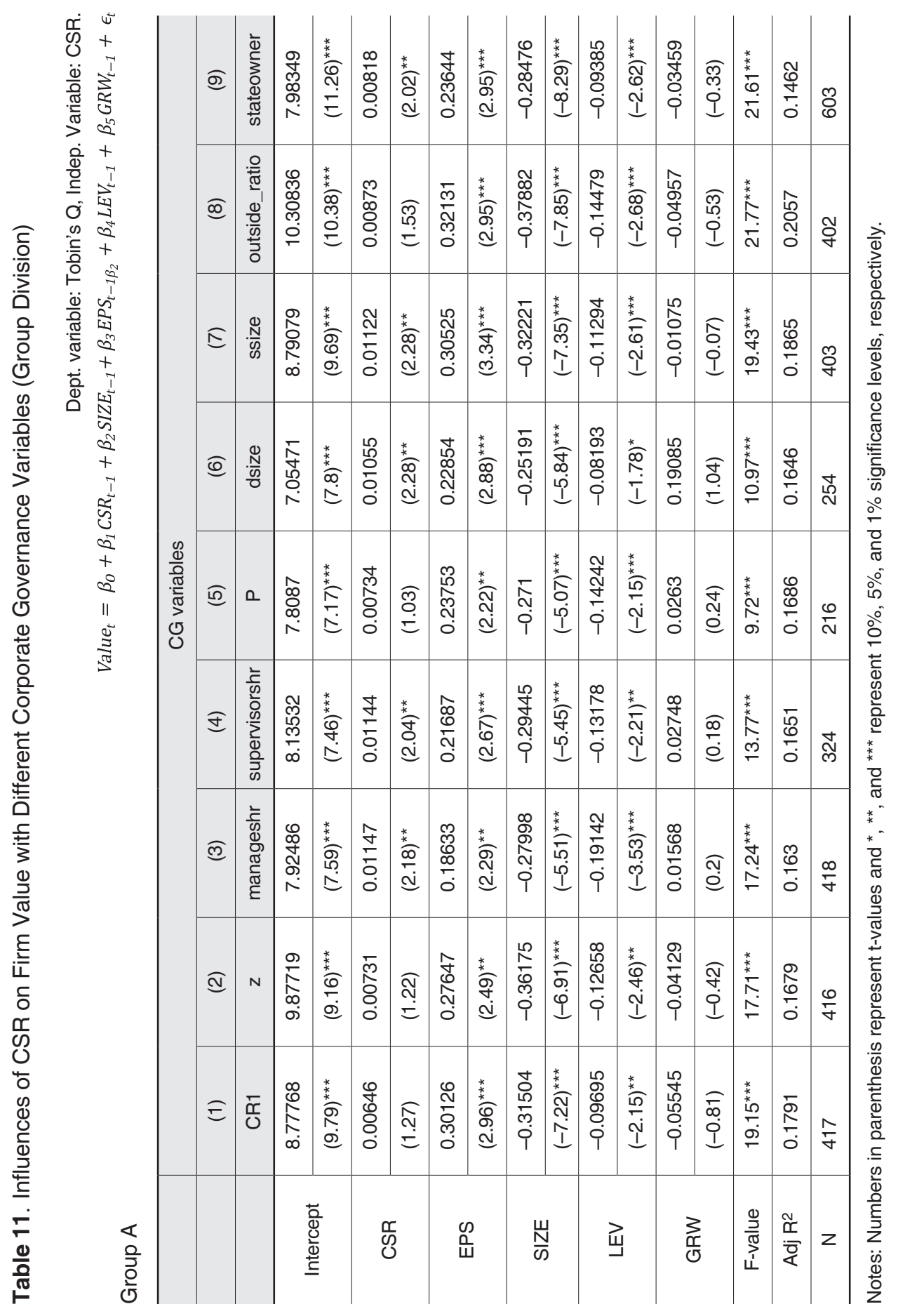




\begin{tabular}{|c|c|c|c|c|c|c|c|c|c|c|c|c|c|c|c|c|c|}
\hline \multirow{9}{*}{ 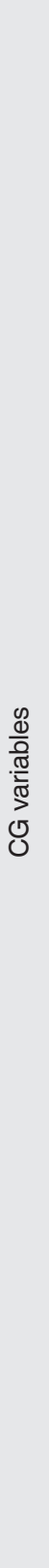 } & () & 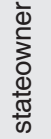 & $\begin{array}{l}\infty \\
\infty \\
\stackrel{\infty}{0} \\
\infty \\
\infty \\
\infty\end{array}$ & 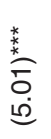 & 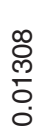 & 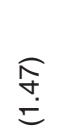 & 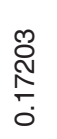 & 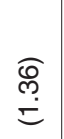 & $\begin{array}{l}\stackrel{\nabla}{N} \\
\text { N } \\
\stackrel{0}{i}\end{array}$ & 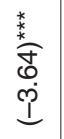 & 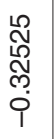 & 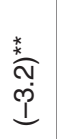 & 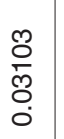 & 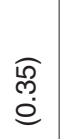 & 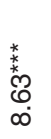 & $\frac{\stackrel{\mathscr{J}}{+}}{\overleftarrow{0}}$ & $\stackrel{\text { Nొ }}{\text { N }}$ \\
\hline & $\widehat{\infty}$ & 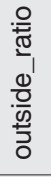 & 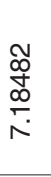 & 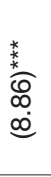 & $\frac{\stackrel{\infty}{0}}{\frac{n}{\sigma}}$ & $\begin{array}{l}\stackrel{*}{*} \\
\stackrel{\text { f }}{\mathfrak{d}}\end{array}$ & $\begin{array}{l}\stackrel{0}{0} \\
\stackrel{0}{0} \\
\frac{0}{0}\end{array}$ & $\stackrel{\stackrel{*}{\mathcal{N}}}{=}$ & 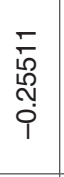 & 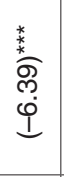 & 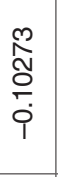 & 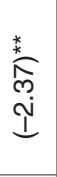 & 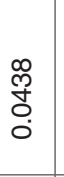 & 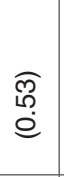 & 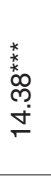 & $\begin{array}{l}\text { م్ } \\
\frac{\text { ־े }}{\circ}\end{array}$ & ণ্ \\
\hline & $\hat{E}$ & 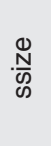 & $\begin{array}{l}\infty \\
\& \\
0 \\
0 \\
\infty\end{array}$ & 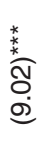 & 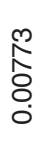 & $\stackrel{\text { ल् }}{=}$ & $\begin{array}{l}\text { N } \\
\text { đิ } \\
\frac{0}{0}\end{array}$ & $\begin{array}{l}\stackrel{*}{0} \\
0 \\
= \\
=\end{array}$ & $\begin{array}{l}\hat{f} \\
\text { D } \\
\text { m } \\
\text { i }\end{array}$ & 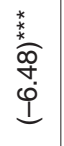 & $\begin{array}{l}\frac{m}{8} \\
\frac{0}{9} \\
\frac{1}{1}\end{array}$ & 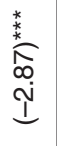 & $\begin{array}{l}\overline{0} \\
\bar{N} \\
\varnothing \\
\grave{i}\end{array}$ & $\begin{array}{l}\text { 尹 } \\
\text { i } \\
\text { I }\end{array}$ & 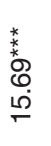 & $\begin{array}{l}\hat{\mathscr{O}} \\
\frac{\sigma}{0}\end{array}$ & 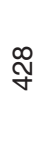 \\
\hline & (6) & $\frac{\mathbb{N}}{\frac{N}{0}}$ & $\begin{array}{l}\underset{N}{N} \\
\text { N్} \\
\text { ஸे }\end{array}$ & $\begin{array}{l}\text { 守 } \\
\text { Oํㅡㄹ }\end{array}$ & 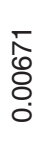 & 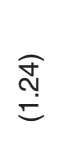 & 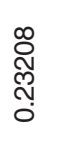 & 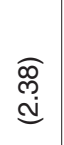 & 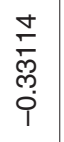 & $\begin{array}{l}\text { तु } \\
\text { I }\end{array}$ & 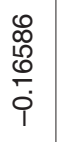 & $\begin{array}{l}\text { g } \\
\stackrel{+}{1} \\
\stackrel{1}{1}\end{array}$ & $\begin{array}{l}\bar{N} \\
\text { Nิ } \\
\text { Oें } \\
\text { i }\end{array}$ & $\begin{array}{l}\text { Q } \\
\dddot{0} \\
\text { I } \\
\text { I }\end{array}$ & 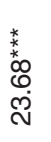 & $\begin{array}{l}\frac{f}{G} \\
\frac{6}{0}\end{array}$ & $\hat{\hat{N}}$ \\
\hline & [0 & 0 & 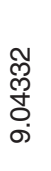 & 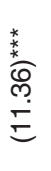 & $\begin{array}{l}\qquad 0 \\
0 \\
0 \\
0 \\
0\end{array}$ & 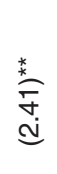 & 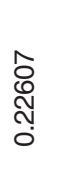 & $\begin{array}{l}\text { t. } \\
\stackrel{3}{8} \\
\stackrel{0}{\mathfrak{d}}\end{array}$ & $\begin{array}{l}\infty \\
\frac{\infty}{\infty} \\
m \\
0 \\
i\end{array}$ & \begin{tabular}{l} 
* \\
\multirow{2}{*}{} \\
$\stackrel{9}{+}$ \\
$\infty$ \\
1
\end{tabular} & $\begin{array}{l}\underset{N}{N} \\
\stackrel{\infty}{N} \\
\stackrel{0}{0} \\
\stackrel{1}{1}\end{array}$ & 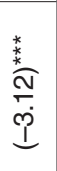 & 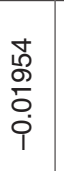 & 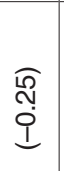 & 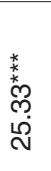 & $\begin{array}{l}\stackrel{4}{0} \\
\frac{0}{0} \\
0\end{array}$ & $\frac{10}{6}$ \\
\hline & $\overparen{\Xi}$ & 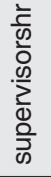 & $\begin{array}{l}\text { : } \\
\text { స్ } \\
\infty\end{array}$ & 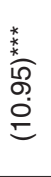 & $\begin{array}{l}\text { ô. } \\
\text { o } \\
0 \\
0 \\
0\end{array}$ & $\begin{array}{l}\stackrel{*}{\infty} \\
\stackrel{0}{\Xi} \\
=\end{array}$ & $\begin{array}{l}\bar{\Lambda} \\
\text { o } \\
\stackrel{N}{0} \\
0\end{array}$ & $\begin{array}{l}\stackrel{*}{*} \\
\stackrel{*}{+} \\
\text { తa }\end{array}$ & 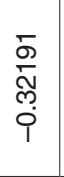 & \begin{tabular}{l} 
* \\
\multirow{2}{*}{} \\
8 \\
$\infty$ \\
1 \\
1
\end{tabular} & 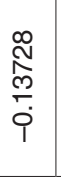 & 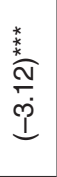 & $\begin{array}{l}9 \\
\mathbb{0} \\
0 \\
0 \\
0 \\
1\end{array}$ & $\begin{array}{l}\widehat{\widehat{N}} \\
\text { ô } \\
\text { I }\end{array}$ & 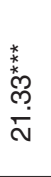 & $\begin{array}{l}\stackrel{M}{\Lambda} \\
\stackrel{6}{0} \\
\stackrel{0}{0}\end{array}$ & 宫 \\
\hline & న్ర & 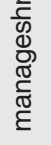 & $\begin{array}{l}\hat{0} \\
\stackrel{0}{0} \\
\varnothing \\
\infty \\
\infty\end{array}$ & 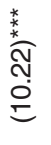 & $\begin{array}{l}0 \\
\& \\
\& \\
0 \\
0 \\
0\end{array}$ & 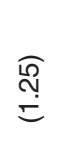 & 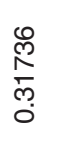 & 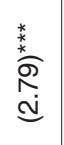 & 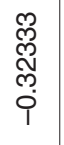 & 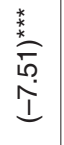 & 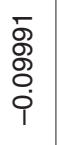 & 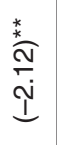 & 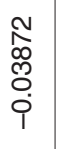 & $\begin{array}{l}\widehat{\infty} \\
\text { ల్ } \\
\text { I }\end{array}$ & 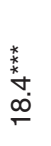 & $\frac{\stackrel{M}{N}}{\frac{N}{0}}$ & $\frac{M}{\frac{M}{\sigma}}$ \\
\hline & $\widehat{\mathbb{N}}$ & $N$ & 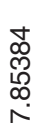 & 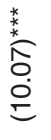 & 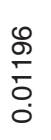 & 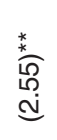 & $\begin{array}{l}\text { \& } \\
\text { مิ } \\
\text { ஸ̦ } \\
0\end{array}$ & 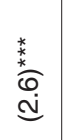 & 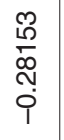 & $\begin{array}{l}\stackrel{*}{*} \\
\stackrel{+}{*} \\
\stackrel{+}{I}\end{array}$ & 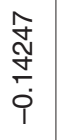 & 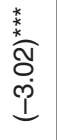 & 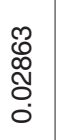 & $\begin{array}{l}\widehat{\mathscr{N}} \\
\stackrel{0}{\varrho} \\
\varrho\end{array}$ & 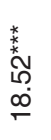 & $\frac{O}{\frac{O}{N}}$ & $\frac{10}{\frac{1}{7}}$ \\
\hline & $\hat{E}$ & $\overline{\text { d }}$ & 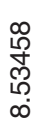 & 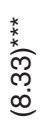 & $\frac{\frac{m}{\sigma}}{\frac{\sigma}{\sigma}}$ & $\begin{array}{l}\stackrel{*}{*} \\
\stackrel{\text { of }}{\stackrel{0}{\mathfrak{d}}}\end{array}$ & $\begin{array}{l}\text { 芯 } \\
\text { م్ } \\
\frac{0}{0}\end{array}$ & $\begin{array}{l}\stackrel{*}{N} \\
\stackrel{N}{=}\end{array}$ & $\begin{array}{l}\stackrel{0}{0} \\
\frac{0}{9} \\
\stackrel{\varphi}{9}\end{array}$ & \begin{tabular}{l} 
* \\
\multirow{x}{*}{} \\
$\hat{N}$ \\
$\underline{1}$
\end{tabular} & 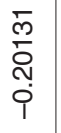 & 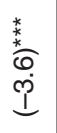 & $\begin{array}{l}\text { N̦ } \\
\text { N̦ } \\
\text { O̦ }\end{array}$ & 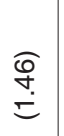 & 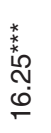 & 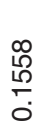 & $\frac{⿱ 亠}{\sigma}$ \\
\hline & & & 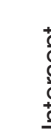 & & & & I & & के & & & & 离 & & $\begin{array}{l}\frac{0}{\frac{D}{\overparen{N}}} \\
\stackrel{\overrightarrow{1}}{\overrightarrow{1}}\end{array}$ & $\begin{array}{l}\frac{\tilde{\alpha}}{\alpha} \\
\frac{\bar{\alpha}}{4}\end{array}$ & $z$ \\
\hline
\end{tabular}


$<$ Table 12> presents the results of the effect of the corporate governance variables on CSR activities and indicates a negative significant coefficient on the CR1 variable. This result implies that the higher largest shareholder stake suggests that those companies perform CSR activities less actively in the interest of shareholders. This result also indicates that, if the largest shareholder of the company is the country, then the company is actively reluctant to perform CSR activities.

Table 12. Panel Analysis of CSR and Corporate Governance Structure

Dep. variable: CSR, Indep. Variable: CG variables

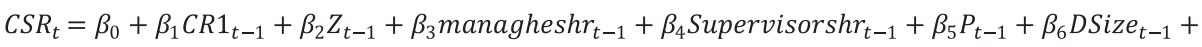
$\beta_{7}$ SSize $_{t-1}+\beta_{8}$ Outside $_{\text {ratio }-1}+\beta_{9}$ Stateowner $_{t-1}+\beta_{10}$ SIZE $_{t-1}+\beta_{11}$ EPS $_{t-1 \beta_{2}}+\beta_{12} L E V_{t-1}+$ $\beta_{13} G R W_{t-1}+\epsilon_{t}$

\begin{tabular}{|c|c|c|c|c|}
\hline Variables & Coeff. & Std. dev. & t-value & $p$-value \\
\hline Intercept & -157.903 & 27.0236 & -5.84 & $<.0001^{\star \star \star}$ \\
\hline CR1 & -13.7306 & 6.8173 & -2.01 & $0.0445^{\star *}$ \\
\hline z & 0.010351 & 0.0141 & 0.74 & 0.4621 \\
\hline manageshr & -47.4146 & 27.0332 & -1.75 & $0.081^{*}$ \\
\hline supervisorshr & 26.17099 & 149.11 & 0.18 & 0.861 \\
\hline$P$ & 0.273508 & 1.1411 & 0.24 & 0.8107 \\
\hline dsize & 0.323896 & 0.3629 & 0.89 & 0.3725 \\
\hline ssize & -0.03742 & 0.4759 & -0.08 & 0.9374 \\
\hline Indep_ratio & 5.068235 & 6.9765 & 0.73 & 0.4679 \\
\hline stateowner & -9.66032 & 2.8029 & -3.45 & $0.0006^{\star * *}$ \\
\hline SIZE & 8.541777 & 1.0337 & 8.26 & $<.0001^{* \star *}$ \\
\hline EPS & 0.417667 & 0.6894 & 0.61 & 0.5449 \\
\hline LEV & -0.55919 & 0.5205 & -1.07 & 0.2831 \\
\hline GRW & -0.98395 & 0.4653 & -2.11 & $0.0349^{* *}$ \\
\hline F-value & \multicolumn{4}{|c|}{4.32} \\
\hline $\mathrm{R}^{2}$ & \multicolumn{4}{|c|}{0.158} \\
\hline $\mathrm{N}$ & \multicolumn{4}{|c|}{554} \\
\hline Time series length & \multicolumn{4}{|c|}{3} \\
\hline Model & \multicolumn{4}{|c|}{ Fixed effect } \\
\hline
\end{tabular}

Notes: Numbers in parenthesis represent t-values and *, **, and *** represent $10 \%, 5 \%$, and $1 \%$ significance levels, respectively. 
Corporate governance is a mechanism that enhances the value of the business and maximizes shareholder value. If CSR positively affects the growth in enterprise value, good corporate governance indicates that those companies should perform more CSR activities that have lower agency costs. Therefore, a lower ownership stake of the largest shareholder and of management positively affects CSR activities, which is consistent with prior results.

\section{Robustness test}

We now consider the endogeneity problem of the CSR variable. Conversely, CSR activities may have positive effects on firm value; however, initially high-value businesses or large enterprises can also engage in more CSR activities. In this case, the CSR variable becomes the endogenous variable, meaning that the conventional ordinary least squares method can no longer provide an unbiased consistent estimator.

Two-stage least squares (2SLS) with instrumental variables were used for the average of the annual CSR score for that industry. Industry characteristics can be associated with firms' CSR activities but are not expected to directly affect the value of the company (Surroca et al. 2010). Therefore, the industry average annual CSR score may be regarded as appropriate as an instrumental variable used to estimate the CSR variable in the 2SLS analysis.

Among the previously analyzed results, only the significant results are the target of the 2 SLS analysis using a group division regression. $<$ Table $13>$ provides the results of the 2SLS analysis using the annual industry average CSR score as an instrumental variable. Panel A indicates the results of the first stage regression and Panel B indicates the results of the second-stage regression.

The first stage regression analysis is used to estimate the CSR industry average score (CSR_indumean). This regression shows statistically significant positive $(+)$ coefficients on all variables. In the second stage regression analysis, the CSR estimate in the first stage (predicted CSR value) is used as an explanatory variable. The regression also presents statistically significant coefficients on variables such as CR1 and Stateowner. Overall, the impact of CSR on firm value is still valid after controlling for the endogeneity problems of the CSR variable that may arise. 


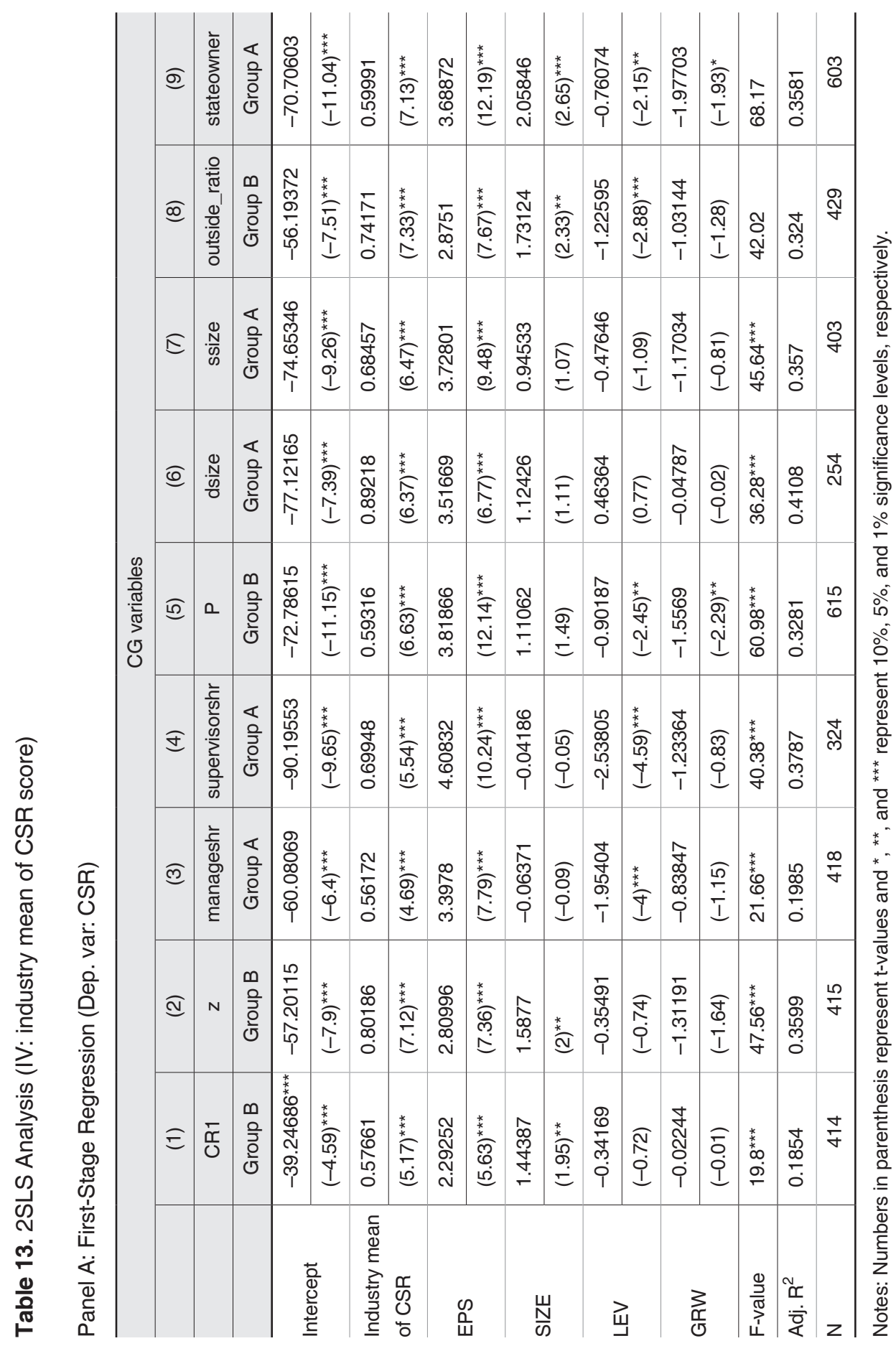




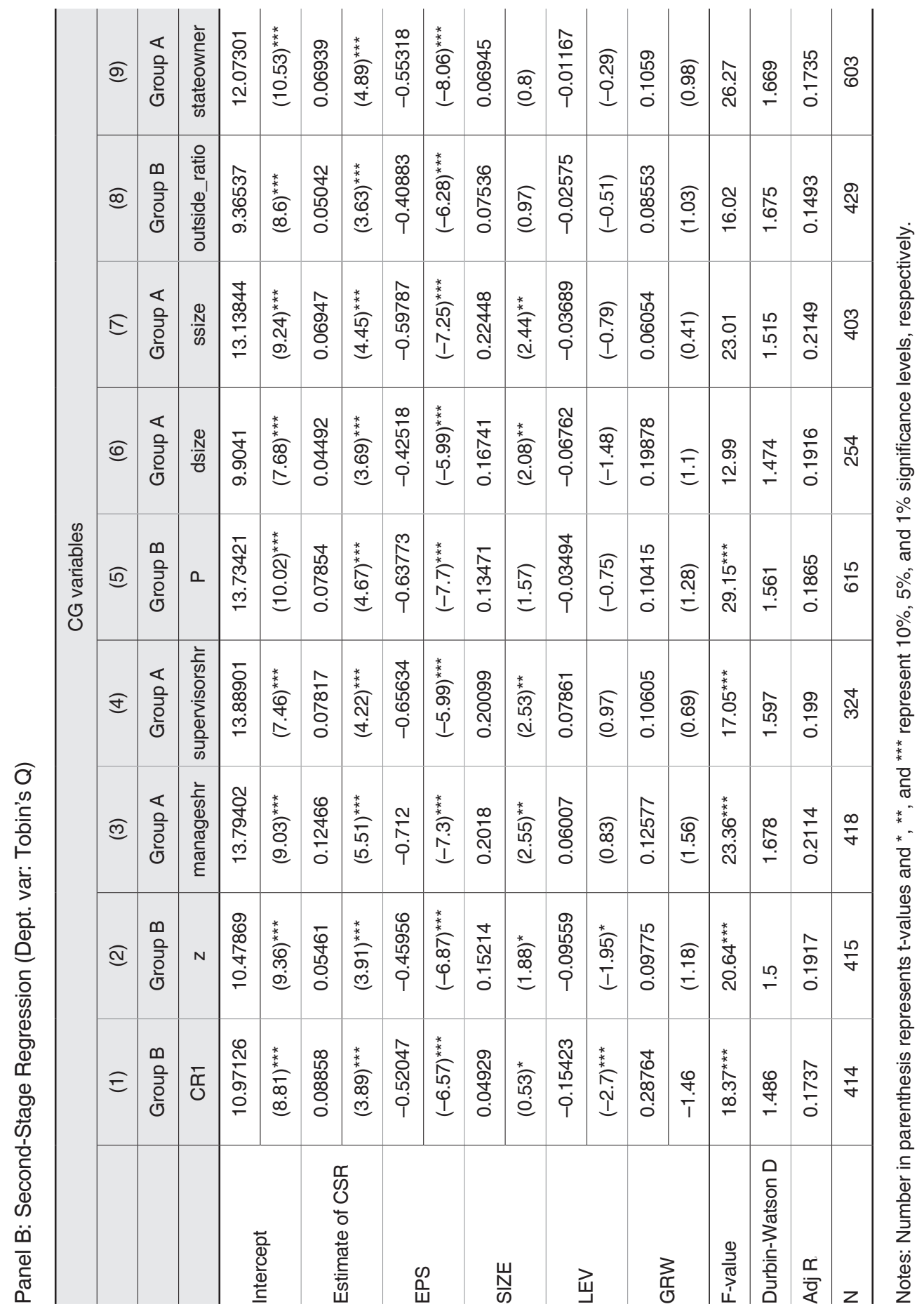




\section{CONCLUSIONS}

Corporate social responsibility has emerged as an important issue with the globalization of the world economy. In particular, the importance of CSR activities is more pronounced for Chinese companies, which have enjoyed high economic growth, and this growth has caused significant negative side effects on society at the same time. If CSR has an impact on increases in firm value, companies with better corporate governance or lower monitoring costs should be more actively involved in CSR activities.

In this paper, we provide an empirical analysis of the impacts of CSR activities of Chinese companies on firm value and - depending on the different level of the corporate governance measures - analyze the effects of CSR activities on firm value. Depending on the level of corporate governance measures, the effects of CSR activities on firm value are expected to be different.

The main results are as follows. First, CSR activities generate a positive effect on firm value. This result suggests that companies may have an incentive to be willing and to continue to perform their CSR activities. Second, if the ratio of the largest shareholder's stake is low (high) or the gap between the largest and the second-largest shareholder's stakes is small (large), CSR activities lead to a significant positive (or negative) impact on firm value. Third, if executives' shareholding ratio or the audit committee's ownership is high or if the CEO and the chair are different individuals, then CSR activities are carried out to benefit the company and enhance firm value. Fourth, a positive effect of CSR activities on firm value is observed for companies with large boards of directors and audit committees. This effect occurs because larger boards and audit committees imply better corporate monitoring, thus reducing agency costs. In contrast, if the ratio of outside directors is relatively low, the influence of CSR activities on firm value is positive. Because outside directors in many Chinese companies are typically appointed by major shareholders, it is no surprise that these outside directors may choose CSR activities that serve these shareholders' private interests rather than the interests of all shareholders. Finally, if the state is the largest shareholder of a company, CSR activities positively impact firm value because they are performed for social benefit instead of for private interests. Overall, CSR activities have a positive impact on firm value for companies with good corporate governance but not for companies with poor corporate governance.

This study is important because it presents the first empirical evidence that examines whether CSR activities are associated with improved financial value depending on the different corporate governance measures for Chinese companies. This article contributes to the debate on the role of CSR in corporate strategy. It also sheds light on the corporate governance structure that can enhance the performance of CSR activities 
and, eventually, firm value. This study can alert policymakers in developing countries such as China to the increasing overlap between corporate governance and CSR agendas, the need to reform the regulatory and judicial systems from the context of corporate governance structure, and the need to increase institutional pressures to enhance CSR adoption.

However, this study has some caveats. For example, a panel data approach using a sample period of three years with a one-year lag may not be appropriate given the shorter period. The sample consists of only companies with available CSR scores for the entire sample period, thus generating a sample selection bias issue. Future research needs to address these problems by expanding the sample period for the panel data and adjusting the sample selection bias using appropriate econometric methods.

\section{REFERENCES}

Allen, F., J. Qian and M. Qian (2005). Law, Finance, and Economic Growth in China, Journal of Financial Economics 77, pp. 57-116.

Beasley, M. S., Carcello, J. V., Hermanson, D. R., \& Lapides, P. D. (2000). Fraudulent financial reporting: Consideration of industry traits and corporate governance mechanisms. Accounting Horizons, 14(4), 441-454.

Beltratti, A. (2005). The complementarity between corporate governance and corporate social responsibility. The Geneva Papers on Risk and Insurance-Issues and Practice, 30(3), 373-386.

Berle, A. A., \& Gardiner, C. (1932). Means, the modern corporation and private property. New York: Macmillan, 3, 45.

Boyd, B. K. (1995). CEO duality and firm performance: A contingency model. Strategic Management Journal, 16(4), 301-312.

Bragdon, J. H., \& Marlin, J. (1972). Is pollution profitable. Risk Management, 19(4), 9-18.

Cochran, P. L., \& Wood, R. A. (1984). Corporate social responsibility and financial performance. Academy of Management Journal, 27(1), 42-56.

Donaldson, L., \& Davis, J. H. (1991). Stewardship theory or agency theory: CEO governance and shareholder returns. Australian Journal of Management, 16(1), 49-64.

Fama, E. F., \& Jensen, M. C. (1983). Separation of ownership and control. Journal of Law and Economics, , 301-325.

Florackis, C. (2008). Agency costs and corporate governance mechanisms: Evidence 
for UK firms. International Journal of Managerial Finance, 4(1), 37-59.

Friedman, M. (1970). The social responsibility of business is to increase its profits". the new york times company. New York,

Jensen, M. C. (1993). The modern industrial revolution, exit, and the failure of internal control systems. The Journal of Finance, 48(3), 831-880.

Jensen, M. C., \& Meckling, W. H. (1976). Theory of the firm: Managerial behavior, agency costs and ownership structure. Journal of Financial Economics, 3(4), 305-360.

Kren, L., \& Kerr, J. L. (1997). The effects of outside directors and board shareholdings on the relation between chief executive compensation and firm performance. Accounting and Business Research, 27(4), 297-309.

Leech, D., \& Leahy, J. (1991). Ownership structure, control type classifications and the performance of large british companies. Economic Journal, 101(409), 14181437.

Mace, M. (1986). Directors: Myth and reality (harvard business school press, boston, MA). MaceDirectors: Myth and Reality1986,

McWilliams, A., \& Siegel, D. (2000). Corporate social responsibility and financial performance: Correlation or misspecification? Strategic Management Journal, 21(5), 603-609.

Morck, R., Shleifer, A., \& Vishny, R. W. (1988). Management ownership and market valuation: An empirical analysis. Journal of Financial Economics, 20, 293-315.

Pfeffer, J., \& Salancik, G. R. (2003). The external control of organizations: A resource dependence perspective Stanford University Press.

Preston, L. E., \& O’bannon, D. P. (1997). The corporate social-financial performance relationship. Business and Society, 36(4), 419-429.

Shleifer, A., \& Vishny, R. W. (1986). Large shareholders and corporate control. The Journal of Political Economy, 94(3), 461.

Stulz, R. (1990). Managerial discretion and optimal financing policies. Journal of Financial Economics, 26(1), 3-27.

Sun, Q., Tong, W. H., \& Tong, J. (2002). How does government ownership affect firm performance? evidence from china's privatization experience. Journal of Business Finance \& Accounting, 29(1-2), 1-27.

Surroca, J., Tribó, J. A., \& Waddock, S. (2010). Corporate responsibility and financial performance: The role of intangible resources. Strategic Management Journal, 31(5), 463-490.

Tsoutsoura, M. (2004). Corporate social responsibility and financial performance.

Ullmann, A. A. (1985). Data in search of a theory: A critical examination of the relationships among social performance, social disclosure, and economic perfor- 
mance of US firms. Academy of Management Review, 10(3), 540-557.

Vance, S. C. (1975). Are socially responsible corporations good investment risks. Management Review, 64(8), 19-24.

Waddock, S. A., \& Graves, S. B. (1997a). The corporate social performance. Strategic Management Journal, 8(4), 303-319.

Waddock, S. A., \& Graves, S. B. (1997b). The corporate social performance. Strategic Management Journal, 8(4), 303-319.

Westphal, J. D. (1998). Board games: How CEOs adapt to increases in structural board independence from management. Administrative Science Quarterly, 511-537.

World Economic Forum (2015), "Is corporate social responsibility China's secret weapon?", https://www.weforum.org/agenda/2015/03/is-corporate-socialresponsibility-chinas-secret-weapon/

Zahra, S. A., \& Pearce, J. A. (1989). Boards of directors and corporate financial performance: A review and integrative model. Journal of Management, 15(2), 291334.

Kook \& Gang (2011), Corporate Social Responsibility, Corporate Governance and Firm Value, Korean Journal of Financial Studies, 40(5), 713-748 (in Korean) 국 찬표, \& 강윤식. (2011). 기업의 사회적 책임, 지배구조 및 기업가치. 한국증권학회 지, 40(5), 713-748.

Changsoo Kim (2009), Corporate Social Responsibility and Firm Value, Korean Journal of Financial Studies, 38(4), 507-545 (in Korean) 김창수. (2009). 기업의 사회 적 책임 활동과 기업가치. 한국증권학회지, 38(4), 507-545.

Mi Hwa Choi (2013), The Moderating Effect of Corporate Governance on the Relations between Corporate Social Responsibility and Cost of Capital, Korea International Accounting Review, Vol. 51, 10, 335-356 (in Korean) 최미화. (2013). 기업의 사회적 책임, 지배구조, 자본비용 간의 관련성. 국제회계연구, 51, 335-356.

Yuanyuan Liu, Zhuo Huang, Xiaofeng He (2011), Equity Structure and Corporate Performance: An Empirical Analysis of Chinese Listed Companies, Research on Economics and Management, (2), 24-32. (in Chinese) 刘媛媛, 黄卓, 谢德逊, \& 何小锋. (2011). 中国上市公司股权结构与公司绩效实证研究. 经济与管理研究, (2), 24-32.

Guanmin Liao \& Yan Chen (2007), State - owned properties, corporate characteristics and difficulties, Accounting Research, (3), 33-41. (in Chinese) 廖冠民, \& 陈燕. (2007). 国有产权, 公司特征与困境公司绩效. 会计研究, (3), 33-41.

Xiaodong Xu, Xiaoyue Chen (2003), Analysis on the Impact of the First Major Shareholder on Corporate Governance and Enterprise Performance, Economics Research, 2(10). (in Chinese) 徐晓东, \& 陈小悦. (2003). 第一大股东对公司治 
理, 企业业绩的影响分析. 经济研究, 2(10).

Zheng Li (2006), Research on the Correlation between Corporate Social Responsibility and Enterprise Value- Empirical evidence from listed companies in Shanghai, China Industrial Economy, (2),77-83 (in Chinese) 李正. (2006). 企业社会责任 与企业价值的相关性研究——来自沪市上市公司的经验证据. 中国工业经济, (2), 77-83.

Xuemei Wang \& Hua Pu (2012), Corporate governance and corporate social responsibility research, Friends of Accounting, (14), (83-86) (in Chinese) 王雪梅, \& 卜 华. (2012). 公司治理与企业社会责任关系研究. 会计之友, (14), 83-86.

Lihui Tian (2005), State - owned properties, soft budget constraints and leverage of Chinese listed companies, Management World, 7(4), 26-37 (in Chinese) 田利辉. (2005). 国有产权, 预算软约束和中国上市公司杜杆治理. 管理世界, 7(4), 26-37.

Wenwu Xie (2011), Research on the Relationship between Corporate Governance and Corporate Social Responsibility, Modern Finance and Economics-Journal of Tianjin University of Finance and Economics, (1), 91-96. (in Chinese) 谢文武. (2011). 公司治理环境对企业社会责任的影响分析. 现代财经: 天津财经学院学报, (1), 91-96.

Xinyuan Chen \& Jun Huang (2007), Government intervention, diversification and corporate performance, Management World, (1), 92-97. (in Chinese) 陈信元, \& 黄 俊. (2007). 政府干预, 多元化经营与公司业绩. 管理世界, (1), 92-97.

Qingyun Ma (2013), A Study on Corporate Social Responsibility from the Perspective of Independent Directors - From the Perspective of Stakeholders' Common Governance Defects, Communication of Finance and Accounting, (10), 92-95马青云. (2013). 基于独立董事视角的企业社会责任研究一一从利益相关者 共同治理缺陷谈起. 财会通讯: 综合 (下), (10), 92-95. 
